\title{
$\mathrm{C}|\mathrm{E}| \mathrm{D}|\mathrm{L}| \mathrm{A} \mid \mathrm{S}$
}

Centro de Estudios

Distributivos, Laborales y Sociales

Maestría en Economía

Universidad Nacional de La Plata

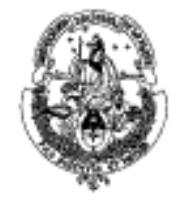

\section{Payroll Taxes, Wages and Employment: Identification through Policy Changes}

Guillermo Cruces, Sebastian Galiani y Susana Kidyba

Documento de Trabajo Nro. 93

Enero, 2010 


\title{
Payroll Taxes, Wages and Employment: Identification through Policy Changes
}

\author{
January 2010 \\ Guillermo Cruces* \\ Sebastian Galiani** \\ and Susana Kidyba***1
}

\begin{abstract}
This paper investigates the effect of changes in payroll taxes on wages and employment in Argentina. The analysis, based on administrative data, focuses on the impact of a series of major changes in payroll taxes which varied across geographical areas. This setup offers two main advantages over previous studies. First, using longitudinal data, the variation in tax rates across space and time provides a plausible source of identification of their effects on employment and wages. Second, the use of legal tax rates for each area at each point in time provides a remedy for the measurement error bias raised by the use of empirical rates constructed from observed tax and wage bills. Once this bias is accounted for, the results indicate that changes in payroll tax rates are only partially shifted onto wages, and they point to the absence of any significant effect on employment.
\end{abstract}

\footnotetext{
1 * Centro de Estudios Distributivos Laborales y Sociales [Center for Social, Labor and Distributional Studies] (CEDLAS), National University of La Plata, and Consejo Nacional de Investigaciones Científicas y Técnicas [National Scientific and Technical Research Council] (CONICET). ** Washington University in Saint Louis, United States. *** Instituto Nacional de Estadística y Censos [National Statistics and Censuses Institute] (INDEC), Argentina. We would like to thank Claudia Giacommetti and Juan Martin Moreno for their comments and help with the data. We also thank the editor and two anonymous referees for very useful comments.
} 


\section{Introduction}

The appropriate level of payroll taxes and their influence on labor markets are hotly debated issues (see, among others, Nickell and Layard, 1999). While such taxes usually constitute an important source of government revenue, they drive a wedge between the cost of labor for a firm and the net wage of the worker, and may therefore have distortional effects on the functioning of the labor market. The introduction of a payroll tax implies a downward shift in the labor demand schedule equivalent to the amount of the tax, and standard partial equilibrium incidence analysis states that the extent of shifting from employers to workers depends on the elasticities of labor demand and supply.

However, taxes and social security contributions do not necessarily reduce workers' perceived income. Social security contributions may also be regarded as deferred consumption when they take the form, for example, of contributions to public pension programs (Summers, 1989). The introduction of a new payroll tax will presumably translate into an outward shift of the labor supply curve, thereby increasing the negative effect of the tax on wages but reducing its impact on employment (Gruber and Krueger, 1990). Such adjustments could be prevented, however, through the use of bargaining systems that preclude downward adjustments in wages (Dolado et al., 1996). In the case we study in this paper, however, it is unlikely that workers would perceive any significant change in their permanent income through future payroll-tax induced revenues. Thus, there would only be a downward shift in the demand schedule as a result of the changes in payroll-taxes studied in this paper.

The relative levels of labor demand and supply elasticities, the presence of offsets, and the resulting incidence of the payroll tax are, ultimately, empirical questions, although there is a relatively small amount of definitive evidence on the subject. Earlier studies include Brittain's (1971) cross-country analysis, which finds full shifting of the tax to the worker's remuneration, and Holmlund (1983), which finds partial shifting based on time series evidence from the Swedish economy. Most of the shortcomings of cross-country and time series studies are overcome by Gruber's (1997) influential study of Chile's 1981 major social security reform and the resulting reduction of payroll taxes by around 25 percentage points. This study, based on a 
panel survey of manufacturing plants, compares wages and employment before and after the reform and finds evidence of a full shifting of taxes to wages, with no significant employment effects. Gruber's (1997) data, however, contain no information on the statutory tax rates applied to each company, which are conjectured to have changed across the board for the whole country at one point in time. His study relies on firm-specific empirical tax rates that are calculated by dividing total tax payments by wages. Despite the advantage of having information on the actual tax liability for every firm in the panel, any shock and/or measurement error in wages (the dependent variable) will be reflected as a spurious correlation in the regression results, since the tax rate is by definition a function of wages.

Our study exploits a series of major policy shifts in labor taxation which were introduced in Argentina during the period 1995-2001, following a social security reform and other marketoriented changes in the economy. The setting, a middle-income developing country in South America, is reminiscent of Gruber's (1997) Chilean study. However, the Argentine policy reform varied by region, while the Chilean study and later contributions to the literature (Kugler and Kugler, 2003) are based on uniform economy-wide changes or on firm-varying tax levels (Anderson and Meyer, 1997; Murphy, 2007). Starting from an almost uniform national payroll tax level, the Argentine reform introduced a wide range of rates that varied by geographical area. Moreover, the full set of region-specific legal tax rates were reconstructed from the relevant laws, executive orders ("decretos") and the software created by the tax authorities which is used by firms to compute tax liabilities. ${ }^{2}$ Full information is available on the exact legal tax rates applying to firms in each of the regions of the country, which eliminates the problems of spurious regression that might arise from purely observational tax rates. ${ }^{3}$

These three characteristics (geographical variation, time variation and the availability of exact legal tax rates) constitute the backbone of the identification strategy pursued below. In the spirit of Gruber and Krueger (1990) and of Besley and Burgess (2004), the unit of analysis is a

\footnotetext{
${ }^{2}$ The working paper version of this article reports the relevant decrees and presents examples of the tax software used by firms to compute payroll tax liabilities (Cruces, Galiani and Kidyba, 2010).

${ }^{3}$ While this is also true in Anderson and Meyer's (1997) and Murphy's (2007) studies of unemployment insurance tax rates in the United States, the presence of experience rating effectively introduces a firm-specific component into the tax rate, and there is, consequently, no single uniform tax rate by geographical area in these studies.
} 
geographical area, and the study is based on an administrative panel dataset containing monthly aggregates of payroll, tax and employment figures.

The following section presents a brief account of the institutional setting for the Argentine labor market and its reform during the period under study. Section 3 describes the data and the construction of the variables used in the analysis. Section 4 presents the main empirical results, and Section 5 describes a series of robustness checks. Conclusions follow.

\section{Payroll taxes in Argentina during the 1990s}

When a new administration took office in 1989, a series of market-oriented structural reforms were introduced in the Argentine economy. In 1991, the Federal Government consolidated the level of payroll taxes ${ }^{4}$ at 33 percent of the wage for employers and at 16 percent for employees, resulting in a total non-wage labor cost of 49 percent of the wage. ${ }^{5}$ A major social security reform was established by Act 24.241 of September 1993. This statute mandated a new, fully funded pension system, which both new workers and those in the existing pay-as-you-go regime could join. It also provided a unified framework for the collection and distribution of employer and employee contributions to the social security system. The data used in this paper is taken from this administrative source, which went online in July 1994.

Based on the belief that lower taxes would reduce unemployment and promote the formalization of the labor market, the social security reform law also gave the Executive the power to diminish the "tax incidence on labor costs". The main policy instrument was the determination of payroll tax "reduction coefficients" by geographical area and the subsequent modification of these

\footnotetext{
${ }^{4}$ Firms were required to make just one total payment to the tax bureau. The payroll tax rate was in fact the sum of a series of different components that were subsumed into this payment. Some areas in the sparsely populated provinces of the Patagonia region in the south of the country had traditionally benefited from a rebate in one of these components (family allowances), which is why the rates were not completely uniform across the country. MTSS (1998) and Neffa (2005) provide an in-depth account of labor and social security regulations during this period.

${ }^{5}$ While payroll tax rates were modified, the definition of taxable income and the tax ceiling (the upper limit on the wage sum to which the tax rate was applied) for individual wages were constant and uniform across the country, which reduces the variation to only one dimension (Murphy, 2007). The ceiling refers to the computation of the payroll tax and was not affected by the tax changes - full payroll taxes $t$ or reduced rates $t(1-c)$ were applied throughout the period to wages in the zero-ceiling interval. Moreover, employee contributions were unaffected over the period under study.
} 
coefficients. In terms of tax administration, Argentina is divided into 85 areas. $^{6}$ In December 1993, an executive order was issued that assigned a "reduction coefficient" $c$ ranging from 30 to 80 percent (11 coefficients in 5 percentage-point steps) to each of these areas. Each area's payroll tax thus corresponded to the national rate, $t$, reduced proportionally by this coefficient: $t(1-c)$. Taxes were thus reduced from an almost uniform rate of 33 percent to a range of values between 6.6 and 23.1 percent (corresponding to the extreme cases of 80 percent and 30 percent reductions, respectively). The first panel in Table 1 presents the summary statistics on the reduction coefficients for the 85 administrative areas.

Table 1: Payroll tax rates and area characteristics

\begin{tabular}{lccccccc}
\hline & Areas & $\begin{array}{c}\text { Simple } \\
\text { Average }\end{array}$ & $\begin{array}{c}\text { Std. } \\
\text { Dev. }\end{array}$ & Min. & Max. & $\begin{array}{c}\mathbf{5}^{\text {th }} \\
\text { perc. }\end{array}$ & $\begin{array}{c}\mathbf{9 5}^{\text {th }} \\
\text { perc. }\end{array}$ \\
\hline $\begin{array}{l}\text { Reduction coefficient } \\
\text { (Executive order 2609/93) }\end{array}$ & 85 & 0.59 & 0.11 & 0.30 & 0.80 & 0.40 & 0.75 \\
$\begin{array}{l}\text { Percentage of population } \\
\text { with basic needs deficit }\end{array}$ & 85 & 0.22 & 0.07 & 0.08 & 0.38 & 0.12 & 0.33 \\
$\begin{array}{l}\text { Distance to Buenos Aires in } \\
\text { 1000s of km }\end{array}$ & 85 & 1.07 & 0.57 & 0.00 & 3.15 & 0.41 & 1.89 \\
\hline Legal rate & & & & & & & \\
\hline$\quad$ March 1995 & 85 & 0.233 & 0.037 & 0.165 & 0.330 & 0.171 & 0.297 \\
$\quad$ January 1996 & 85 & 0.163 & 0.028 & 0.104 & 0.239 & 0.118 & 0.212 \\
$\quad$ January 1999 & 85 & 0.163 & 0.028 & 0.104 & 0.239 & 0.118 & 0.212 \\
$\quad$ August 1999 & 85 & 0.138 & 0.022 & 0.092 & 0.197 & 0.102 & 0.176 \\
$\quad$ June 2001 & 85 & 0.138 & 0.022 & 0.092 & 0.197 & 0.102 & 0.176 \\
$\quad$ September 2001 & 85 & 0.210 & 0.000 & 0.210 & 0.210 & 0.210 & 0.210 \\
\hline Empirical rate & & & & & & & \\
\hline$\quad$ March 1995 & 85 & 0.226 & 0.037 & 0.139 & 0.302 & 0.169 & 0.287 \\
$\quad$ January 1996 & 85 & 0.163 & 0.030 & 0.106 & 0.226 & 0.114 & 0.208 \\
$\quad$ January 1999 & 85 & 0.155 & 0.028 & 0.107 & 0.221 & 0.113 & 0.198 \\
$\quad$ August 1999 & 85 & 0.133 & 0.022 & 0.093 & 0.231 & 0.098 & 0.167 \\
$\quad$ June 2001 & 85 & 0.147 & 0.029 & 0.105 & 0.291 & 0.111 & 0.183 \\
$\quad$ September 2001 & 85 & 0.194 & 0.011 & 0.161 & 0.250 & 0.180 & 0.207 \\
\hline
\end{tabular}

The consolidated payroll tax rate of 1991 and the reduction coefficients established in 1993 were the basis of Government interventions on payroll taxes during the 1990s, and provide the source

\footnotetext{
${ }^{6}$ Argentina is a Federal State, which is divided into 23 provinces and one autonomous city. The "areas" defined by the tax bureau do not cross provincial boundaries. These areas usually correspond either to the capital of the province, to one or two major urban areas, or to the rest of the province.
} 
of identification for this study. The coefficients for each of the 85 areas were, by executive order, set on the basis of poverty levels and the distance to the country's capital, Buenos Aires. These criteria were chosen in order to compensate for differential development levels and for location costs, respectively. The regression results shown in the first column of Table 2 indicate that these reduction coefficients are well explained by the criteria mentioned above: distance to Buenos Aires and the percentage of population with basic needs deficits gathered from the 1991 census. Moreover, the reductions were differential within regions, with poorer areas receiving higher reduction coefficients than their richer neighbors, as attested to by the regression shown in the second column of Table 2, where the distance and poverty variables remain significant even after including regional controls. These results are consistent with the assignment of tax reduction coefficients based on pre-established rules, rules that could not be manipulated by the local authorities. $^{7}$ The third and fourth columns of Table 2 present the results from a regression of the resulting "reduced" tax rates $t(1-c)$ in 1995 against the same variables, for all the 85 regions and for the 49 regions upon which our empirical analysis below is based. As expected, these binding legal tax rates are negatively related to poverty and distance to the capital. ${ }^{8}$

This study focuses on the period from the second quarter of 1995 up to the end of 2001, during which labor taxes were mostly uniform within geographical areas. ${ }^{9}$ Over this period, the average level of payroll taxes was modified three times by means of changes in the reduction coefficients $c$. The weighted national aggregates in Figure 1 illustrate these changes: the reduction

\footnotetext{
${ }^{7}$ The process for assigning these coefficients, while cumbersome, was clear and left no room for manipulation from local authorities. The tax reduction coefficients ranged from 30 to 80 percent $(11$ coefficients in 5 percentage-point steps). These coefficients were not assigned arbitrarily to the administrative areas. Each province was assigned one "round" level (i.e., 30 or 50) which was applied to its main urban area. The rest of the province was then assigned a coefficient with 5 more percentage points (for instance, 50 percent for the province capital and 55 for the rest of the province). There was thus no room for manipulation within a province. The allocation of the "round" reduction coefficients by province was determined by the province's structural factors (distance to Buenos Aires and poverty levels in 1991), as shown in Table 2. Also, inspection of the regression residuals (not reported) shows that there are no outliers, which would have been likely to arise in the presence of systematic manipulations of the initial assignment. Finally, while tax levels changed over the period, the "change categories" remained fixed over the period under study, indicating that local governments were not able to change the initial assignment. Further modifications after 1993 were done en masse: all reduction coefficients were increased or decreased by the same amount (i.e., 10, 20 or 30 percentage points).

${ }^{8}$ The same relationship holds at other points in time during our sampling period, and when regional controls are excluded.

${ }^{9}$ The year 1994 and the first quarter of 1995 were discarded because payroll tax rates also varied by sector, which resulted in heterogeneous tax rates within geographical areas. As already mentioned, after this period, the rates were still not completely uniform across geographical areas because of the reduction in the family allowances components in the Patagonia region that prevailed until January 2006.
} 
coefficients were lowered at the end of 1995 and again in early 1999, and then were raised in mid-2001.

The specifics of these changes are as follows: from March to September 1995, payroll taxes in each area corresponded to the full national rate of 33 percent reduced by the coefficients $c$ ranging from 0 to 50 percent, resulting in tax rates from 16.5 to 33 percent. ${ }^{10}$ The coefficients $c$ were then increased by 30 percentage points (in steps of 10 percentage points) over the period October 1995-March 1996, and then remained at those levels until January 1999, resulting in tax levels ranging from 10.4 to 23.9 percent. ${ }^{11}$ The reduction coefficients $c$ were increased again in February-July 1999. Finally, in mid-2001, the coefficients were eliminated and a uniform national payroll tax rate of 21 percent was established. The changes made in these legal tax rates at key turning points are depicted in the second panel of Table 1.

\footnotetext{
${ }^{10}$ The 1995 reduction coefficients correspond to the original 1993 coefficients (ranging from 30 to 80 percent), which were then decreased by 30 percentage points due to fiscal considerations, resulting in $c$ levels of 0 to 50 percent.

${ }^{11}$ The increase in the reduction coefficients included a minor change in the way they were implemented. The health contribution component of 5 percent was excluded from the reduction, resulting in the range reported:

$[0.05+0.27 *(1-0.8)=0.104 ; 0.05+0.27 *(1-0.3)=0.239]$
} 
Table 2: Determinants of payroll tax rate "reduction coefficients"

\begin{tabular}{|c|c|c|c|c|}
\hline \multirow{3}{*}{$\begin{array}{l}\text { Percentage of population } \\
\text { with basic needs deficit } \\
\text { Distance to Buenos Aires }\end{array}$} & \multicolumn{2}{|c|}{$\begin{array}{l}\text { Reduction Coefficient } \\
\text { Executive Order } \\
2609 / 93,1993\end{array}$} & \multicolumn{2}{|c|}{$\begin{array}{l}\text { Legal tax rate, August } \\
\qquad 1995\end{array}$} \\
\hline & $\begin{array}{l}0.776 \\
{[0.111]^{\star * *}}\end{array}$ & $\begin{array}{l}0.519 \\
{[0.103]^{\star * *}}\end{array}$ & $\begin{array}{l}-0.153 \\
{[0.036]^{\star * *}}\end{array}$ & $\begin{array}{l}-0.177 \\
{[0.061]^{\star * *}}\end{array}$ \\
\hline & $\begin{array}{l}0.094 \\
{[0.013]^{\star * *}}\end{array}$ & $\begin{array}{l}0.066 \\
{[0.017]^{\star \star *}}\end{array}$ & $\begin{array}{l}-0.034 \\
{[0.006]^{\star * \star}}\end{array}$ & $\begin{array}{l}-0.036 \\
{[0.009]^{* * *}}\end{array}$ \\
\hline Region: Cuyo & & $\begin{array}{l}0.170 \\
{[0.042]^{\star * *}}\end{array}$ & $\begin{array}{l}-0.039 \\
{[0.015]^{\star \star *}}\end{array}$ & $\begin{array}{l}-0.037 \\
{[0.018]^{\star *}}\end{array}$ \\
\hline Region: NOA (north-west) & & $\begin{array}{l}0.208 \\
{[0.041]^{\star * \star}}\end{array}$ & $\begin{array}{l}-0.056 \\
{[0.014]^{\star \star \star}}\end{array}$ & $\begin{array}{l}-0.055 \\
{[0.019]^{\star * *}}\end{array}$ \\
\hline Region: NOE (north-east) & & $\begin{array}{l}0.292 \\
{[0.044]^{\star * *}}\end{array}$ & $\begin{array}{l}-0.086 \\
{[0.015]^{\star \star *}}\end{array}$ & $\begin{array}{l}-0.081 \\
{[0.019]^{\star * *}}\end{array}$ \\
\hline Region: Pampeana & & $\begin{array}{l}0.147 \\
{[0.035]^{\star * \star}}\end{array}$ & $\begin{array}{l}-0.041 \\
{[0.012]^{\star \star \star}}\end{array}$ & $\begin{array}{l}-0.039 \\
{[0.015]^{\star *}}\end{array}$ \\
\hline Region: Patagonica & & $\begin{array}{l}0.160 \\
{[0.045]^{\star \star \star}}\end{array}$ & $\begin{array}{l}-0.045 \\
{[0.016]^{\star \star *}}\end{array}$ & $\begin{array}{l}-0.036 \\
{[0.022]}\end{array}$ \\
\hline Constant & $\begin{array}{l}0.317 \\
{[0.027]^{\star \star \star}}\end{array}$ & $\begin{array}{l}0.236 \\
{[0.035]^{\star \star \star}}\end{array}$ & $\begin{array}{l}0.349 \\
{[0.012]^{\star \star \star}}\end{array}$ & $\begin{array}{l}0.353 \\
{[0.015]^{\star * *}}\end{array}$ \\
\hline Observations & 85 & 85 & 85 & 49 \\
\hline R-squared & 0.58 & 0.76 & 0.76 & 0.81 \\
\hline
\end{tabular}

Standard errors in brackets; ${ }^{* * *}$ significant at $1 \%$. Omitted region: Greater Buenos Aires metropolitan area. Note: the last column only includes data for the 49 selected areas.

Figure 1: Payroll tax rate reductions and level of employment

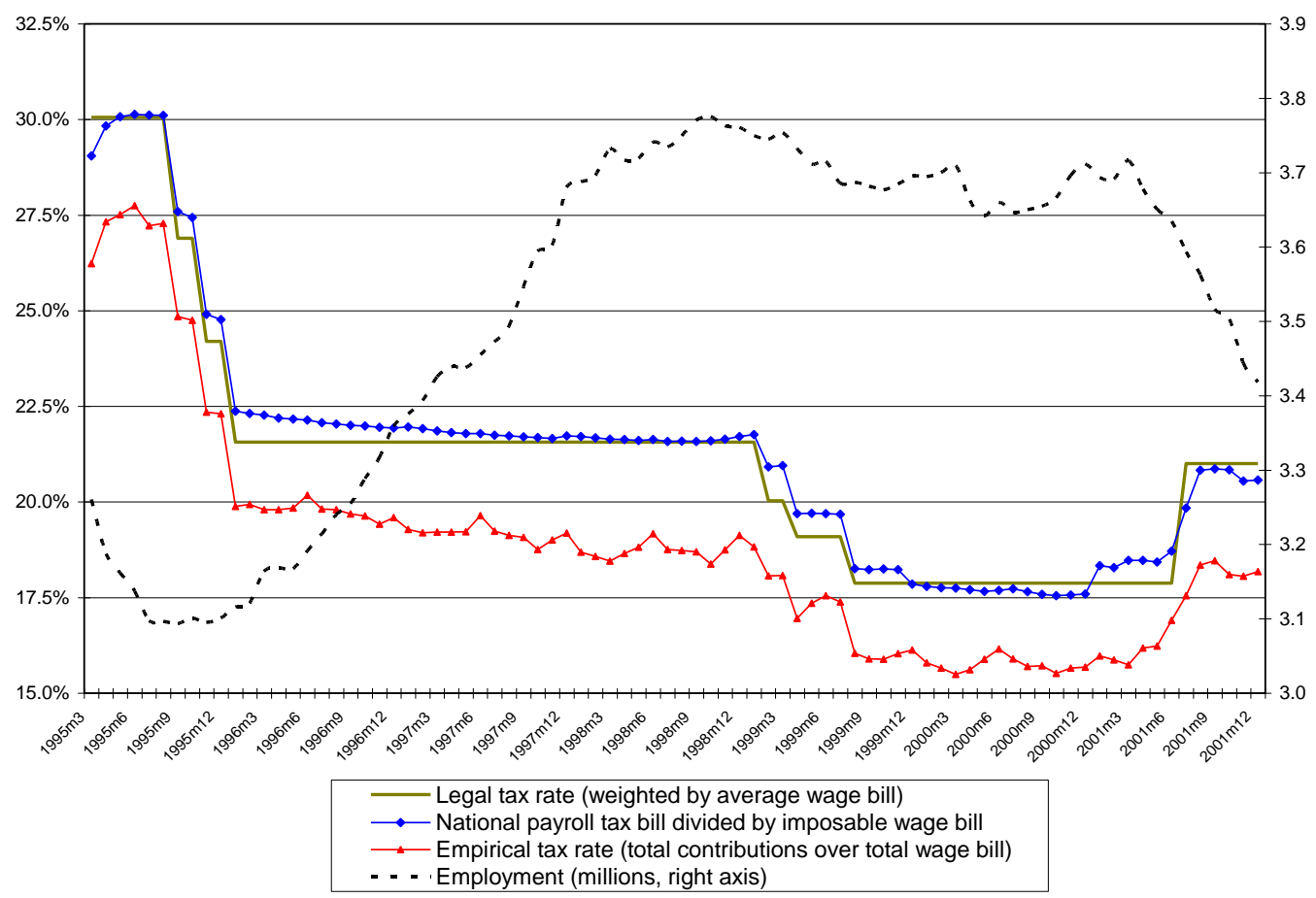




\section{Data}

As stated above, the Argentine tax authority divided the country into administrative areas that were then assigned differing payroll tax rates. This study is based on a panel dataset of these areas that contains monthly aggregates of payroll, tax and employment figures. The unit of analysis is therefore the geographical area. The data are collected on a monthly basis by the Sistema Integrado de Jubilaciones y Pensiones [Integrated Retirement and Pension System] (SIJP), which covers all formal-sector employees in the country (about 60 percent of the workforce over this period). The dataset used in this study excludes agricultural workers (whose employment and wage levels are highly cyclical) and public employees, since the public sector was excluded from the changes in payroll taxation introduced over the period analyzed in this paper. ${ }^{12}$ This selection criterion results in a total count from 3.1 to 3.8 million workers over the period studied (Figure 1). This administrative dataset is supplemented by a carefully constructed set of legally binding taxes for each geographical area based on legislative sources (the laws and executive orders mentioned in the previous section) and on the software created by the tax bureau which is used by firms to compute their tax liabilities (AFIP, 2006).

The data consists of one observation per month $(t)$ by geographical area $(z)$. The variables consist of area aggregates, and they include total monthly employment $E_{z t}$, total monthly wage payments $W_{z t}$, and total monthly payroll tax payments Taxbill ${ }_{z t}{ }^{13}$ These variables are used to define the dependent variables of interest, the logarithm of average wages $\ln \left(\frac{W_{z t}}{E_{z t}}\right)$ and the logarithm of employment $\ln \left(E_{z t}\right)$. The legally binding tax rate corresponding to area $z$ at time $t$ is $T_{z t}^{c}$, while the empirical tax rate for each area is defined as the total tax bill divided by the total wage bill, and thus given by $T_{z t}=\frac{T_{a x b i l_{t}}}{W_{z t}}$. Finally, data are available on the monthly distribution of employment by sector of activity within each area $\left(S_{s z t}, s=1\right.$ to 20$) .{ }^{14}$

\footnotetext{
${ }^{12}$ Provincial public workers were incorporated only gradually into the unified pension system. Private-sector workers have all been in the system since its inception.

${ }^{13}$ The period 1994-2001 was exceptional in that the annual rate of inflation was close to zero during the whole period.

${ }^{14}$ The sectors are: mining, manufacturing, public utilities, construction, commerce, hotels and restaurants, transport and telecommunications, banking and finance, real estate, education and teaching, health, cultural services, domestic
} 
Table 3: Summary statistics (regression variables)

\begin{tabular}{lccccc}
\hline & Obs. & $\begin{array}{c}\text { Simple } \\
\text { Average }\end{array}$ & $\begin{array}{c}\text { Std. } \\
\text { Dev. }\end{array}$ & Minimum & Maximum \\
\hline Legal tax rate & 4018 & 0.163 & 0.043 & 0.092 & 0.330 \\
Empirical tax rate & 4018 & 0.155 & 0.037 & 0.084 & 0.309 \\
Employment (1000s) & 4018 & 70.8 & 177.6 & 2.5 & 1132.9 \\
Log of employment & 4018 & 3.136 & 1.233 & 0.925 & 7.033 \\
Average wage & 4018 & 754.4 & 236.2 & 427.2 & 2022.4 \\
Log of average wage & 4018 & 6.586 & 0.273 & 6.057 & 7.612 \\
\hline
\end{tabular}

These summary statistics correspond to the 49 areas selected for the regressions over the period March 1995-December 2001.

Table 1 presents a series of descriptive statistics of these variables at different points in time for the 85 areas. Since the data include only formal sector employees and exclude public sector and agricultural workers, sparsely populated administrative areas have an extremely low number of workers recorded per month. Data from these areas are prone to measurement error and are highly sensitive to idiosyncratic circumstances. This is evident when comparing the extreme values of the empirical rates in Table 1 with those given for the $5^{\text {th }}$ and $95^{\text {th }}$ percentiles. ${ }^{15}$ For this reason, only areas with at least 2,500 employees per month were retained. ${ }^{16}$ Moreover, the dataset does not include data after December 2001. After the January 2002 economic crisis and devaluation, the new administration introduced a series of changes and exceptions to payroll tax regulations that implied that the rates varied greatly by sector and by type of worker. ${ }^{17}$ This data selection process resulted in a panel of 49 areas spanning 82 months (from March 1995 to December 2001), with a total of 4,018 monthly observations.

The summary statistics of the variables defined above for the selected areas are presented in

services, janitors and building maintenance, private security, research and development, administrative union workers, administrative workers, and others.

${ }^{15}$ For instance, firms might be one month late in paying their tax bill, which would lead to the registration of a very low figure, followed by a very high figure, in the tax payment system. In a large area, this type of error is likely to average out, but in small areas with very few formal-sector employees, a single firm could have a significant effect on the overall empirical tax rate.

${ }^{16}$ Of the 50 areas that matched the selection criteria, one additional area was eliminated because of the very high variability in employment and wages found there, as the standard deviation of these variables was several orders of magnitude higher than it was in the rest of the areas. Anderson and Meyer (1997) discuss the issue of extreme values in administrative data and apply similar selection mechanisms.

${ }^{17}$ It should also be noted that the devaluation of Argentina's currency in January 2002 resulted in an increase in the price level. Inflation and the potential regional heterogeneity in price changes imply a great deal of noise in the real value of wages, one of the two main dependent variables of the analysis in this paper. 
Table 3. As expected, the legal and empirical tax rates vary over a wide range, from 9.2 to 33 percent. The areas also differ markedly in monthly levels of employment, from a low of 2,500 employees to more than 1.1 million workers in the city of Buenos Aires at some point within the observation period. Average salaries, in turn, were 754.4 pesos over the period studied (equivalent to nominal US dollars for the period under study), but ranged from 427.2 to 2,022.4 pesos. These figures reflect the wide geographical variation that exists in income levels and standards of living in Argentina. ${ }^{18}$

\section{Identification strategy and empirical results}

The incidence of the payroll tax rate, and thus its relationship with levels of wages and employment, are estimated by means of ordinary least squares regressions. The basic regressions correspond to empirical models employed previously in the literature:

$$
\begin{aligned}
& \ln \left(\frac{W_{z t}}{E_{z t}}\right)=\alpha+\beta_{1} \operatorname{Tax}_{z t}+\delta_{z}+\tau_{t}+\varepsilon_{z t} \\
& \ln \left(E_{z t}\right)=\mu+\beta_{2} \operatorname{Tax}_{z t}+\delta_{z}+\tau_{t}+\varepsilon_{z t}
\end{aligned}
$$

where the dependent variables are defined as above, the tax variable is either the empirical rate $T_{z t}$ or the legal rate $T_{z t}^{c}, \delta_{z}$ is a set of area fixed effects, $\tau_{t}$ is a set of time period fixed effects, and $\varepsilon_{z t}$ is the residual term. ${ }^{19}$

These regressions correspond to two-way fixed effect error component models. The key identification assumption is that the tax rate is strictly exogenous, conditional on the fixed

\footnotetext{
${ }^{18}$ It should be noted that the range of monthly wages is influenced by the "aguinaldo" (an extra monthly salary per year i.e., a " $13^{\text {th }}$ month's pay", which is customary in some Latin American countries), paid in halves in Argentina in June and December. Excluding these months, the average wage is 698.7 pesos, and the range is reduced to 427.2 $1,465.6$ pesos. All the regressions shown below include month fixed effects that will control for these cyclical increases in the wage bill.

${ }^{19}$ An alternative empirical tax rate can be computed by dividing the tax bill by the taxable (or "imposable") wage aggregate $W_{z t}^{i m p}$, resulting in $T_{z t}^{i m p}=$ Taxbill $_{z t} / W_{z t}^{i m p}$ (the blue line in Figure 1). This aggregate is similar to the total wage bill, but it accounts for minimum and maximum thresholds for payroll taxes and some non-taxable components of the wage bill. It should be noted that these ceilings did not vary over the period under study. While this rate is much closer to the legal one, $T_{z t}$ is used in the previous literature, and its use therefore yields more comparable results. While not reported for space reasons, empirical results using $T_{z t}^{i m p}$ are qualitatively similar to those obtained using $T_{z t}$, although coefficients are lower in absolute terms but consistently higher than those obtained with $T_{z t}^{c}$.
} 
effects. As differences in the levels of the dependent variable are controlled for by these fixed effects, the assumption implies that changes in tax rates are taken to be uncorrelated with changes in unobservables. Section 5 below addresses the challenges to the identification strategy.

The panel dataset used for the estimation spans 82 months and 49 geographical areas. Another source of concern might arise from the high frequency of observations, which could induce serial correlation. However, all of the results below report standard errors clustered at the area level, which implies that no restrictions are imposed on the area level regression residuals. In particular, the residuals are allowed to be correlated over time, and with a relatively large number of clusters (as in this case) this accounts for potential autocorrelation. (Angrist and Pischke, 2008, Chapter 8).

Table 4: Main results

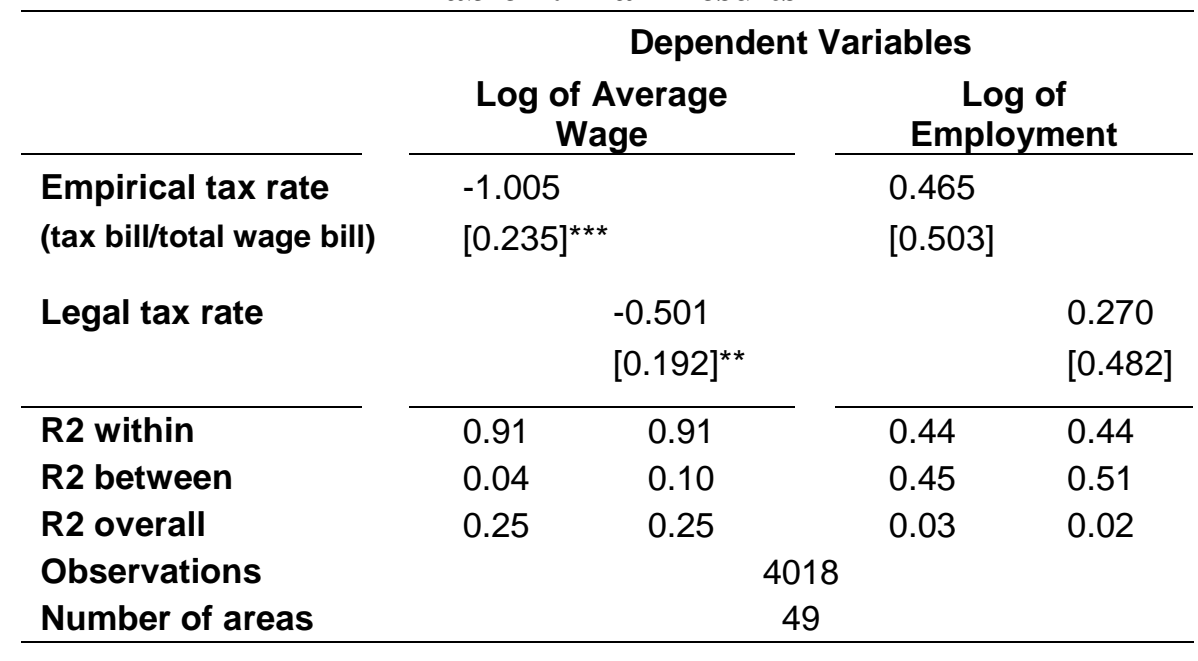

Note: * significant at 10 percent; ** significant at 5 percent; ${ }^{* * *}$ significant at 1 percent. All regressions include 49 area and 82 month fixed effects. Standard errors are clustered at the area level. 
The coefficients $\beta$ from the simple models given by Equations (1) and (2) are presented in Table 4 for both alternative tax rates. The results follow the same pattern, with negative and highly significant coefficients for the wage regressions, and positive coefficients not significantly different from zero for the employment regressions. The coefficient for the empirical tax rate in the monthly wage regressions is -1.005 , which corresponds to the full shifting hypothesis, but the use of the legal tax rate results in a coefficient of -0.501 , about half that value. ${ }^{20}$

This result may shed some light on the previous literature. As suggested by Gruber (1997), measurement error in wages $W_{z t}$ may introduce a spurious correlation between the dependent variable $\ln \left(\frac{W_{z t}}{E_{z t}}\right)$ and the empirical tax rate $T_{z t}=\frac{\text { Taxbil }_{l t}}{W_{z t}}$. In such circumstances, an instrumental variable could capture the exogenous variability in the tax rate beyond this spurious correlation. However, this is not the case in this context. The exact measure of the tax rate $T_{z t}^{c}$ reflects only true variability in tax liability. The results of Table 4 therefore seem to favor the hypothesis of partial shifting of taxes to wages over the hypothesis of full shifting.

\footnotetext{
${ }^{20}$ The coefficients for the empirical and for the legal tax rate in the average wage regression in Table 4 are statistically different at the one percent level of significance. The same qualitative result holds for each pair of average wage regression in Tables 5 and 6: the equality of coefficients is strongly rejected at standard levels of significance. The tests for equality of tax rate coefficients (not reported) are implemented after joint estimation of each pair of equations by seemingly unrelated regression.
} 


\section{Robustness checks}

The key identification assumption in the simple estimations presented above is that the changes in tax rates are not correlated with the changes in unobservables. This assumption faces a series of challenges. It would be invalid, for instance, if there was regression to the mean, that is, if the changes in the tax rates were the response to changes in outcomes. This effect can be ruled out because of the strict rule that assigned changes in tax rates to geographical areas, which stayed fixed during the whole period of analysis, as discussed in Section 2. Another challenge to the identification assumption arises from the possibility that areas might have different secular trends, and these trends might be correlated with the changes in tax rates. To address this concern, the estimations presented in the following pages include controls for regional heterogeneity and region and time-specific controls for unobserved shocks.

The above models do not include any controls other than time and area fixed effects. Since the data are taken from administrative sources, the set of control variables is narrower than it would be in the case of survey data. However, since the data are provided by sector, it is possible to include the share of employment in each sector as additional control variables. The employment shares $S_{s z t}$ can control for time-varying factors within geographical areas not captured by the fixed effects $\delta_{z} \cdot{ }^{21}$ The augmented models are given by:

$$
\begin{aligned}
& \ln \left(\frac{W_{z t}}{E_{z t}}\right)=\alpha+\beta_{1} \operatorname{Tax}_{z t}+\delta_{z}+\tau_{t}+\sum_{s} \pi_{s} S_{s z t}+\varepsilon_{z t} \\
& \ln \left(E_{z t}\right)=\mu+\beta_{2} \operatorname{Tax}_{z t}+\delta_{z}+\tau_{t}+\sum_{s} \pi_{s} S_{s z t}+\varepsilon_{z t}
\end{aligned}
$$

The corresponding results are reported in the first panel of Table 5 for the empirical and the legal tax rates. A comparison between the coefficients in the first panel of Table 5 and those in Table 4 suggests that the sector employment controls do not modify the qualitative nature of the original results; the coefficients of the tax rates in the wage regressions are negative and highly significant, while those in the employment regressions are not significantly different from zero. ${ }^{22}$

\footnotetext{
${ }^{21}$ Moreover, the tax rate varied by sector between February and July 1999 and again from July 2001 onward, so the inclusion of these variables may control for the differences in tax rates within areas.

${ }^{22}$ The comparison of results in Tables 4 and 5 also indicates a difference in measures of goodness of fit. The "within" R squared corresponds to the R squared from an OLS regression with de-meaned variables, and it naturally increases when adding the employment-sector controls. The "between" and "overall" statistics, however, are squared correlations and do not have the properties of OLS R squares (StataCorp, 2009). Specifically, the "between" statistic increases when adding sector controls in the log wage regressions, but it diminishes drastically for the $\log$ employment estimations. Since the "between" R squared is the squared correlation between the means of the
} 
The difference between estimates with the empirical and the legal tax rate still holds: the use of the empirical tax rate biases the coefficient downward and away from zero. The main difference is that the coefficients in the wage regressions are about 20 percent higher (in absolute value) when these controls are introduced. The coefficient of the legal tax rate of -0.644 still indicates less than full shifting.

The identification of the payroll tax effect in the models of Equations (1)-(4) is given by the differential evolution over time of the payroll tax rates across the 49 areas used in the analysis. However, as discussed above and shown by the summary statistics in Tables 1 and 3, these areas are heterogeneous, ranging from large and relatively affluent cities to smaller and poorer areas. It is therefore possible that these areas would have had different secular trends of wages and employment even if payroll taxes had not changed. To verify that the identified effects are not an artifact of differential secular trends across regions, the models in Equations (5) and (6) incorporate time controls interacted with a series of different area grouping indicators $G_{j}$ :

$$
\begin{aligned}
& \ln \left(\frac{W_{z t}}{E_{z t}}\right)=\alpha+\beta \operatorname{Tax}_{z t}+\delta_{z}+\tau_{t}+\sum_{s} \pi_{s} S_{s z t}+\sum_{j} \tau_{t} G_{j}+\varepsilon_{z t} \\
& \ln \left(E_{z t}\right)=\alpha+\beta \operatorname{Tax}_{z t}+\delta_{z}+\tau_{t}+\sum_{s} \pi_{s} S_{s z t}+\sum_{j} \tau_{t} G_{j}+\varepsilon_{z t}
\end{aligned}
$$

These models add a full set of interactions between the time period and the $G_{j}$ grouping variables. The second and third panels of Table 5 present the results of these models with two alternative groupings defined as follows: in the second panel, the areas were ranked by their average level of employment over the whole period and were then divided into 9 groups of 5 and one group of 4 (corresponding to the four largest units). In the third panel, a similar procedure was followed, except that the 10 groups were obtained by ranking areas by average wages. In the fourth panel, the 49 areas were evenly divided into three broad geographical regions: the North, the Center (including the Pampeana and Buenos Aires Metropolitan Areas) and the South (including Cuyo and Patagonia). As in the first panel, all the regressions also include the controls for employment-sector distribution.

predicted values and the means of the actual values of the dependent variable, this indicates that the fixed effects in Table 4 regression's were capturing mean levels of employment, but that the addition of time-varying sector controls might increase the precision of the prediction over time but not necessarily for average values. 
Table 5: Robustness checks (sector controls and time/category interactions)

\begin{tabular}{|c|c|c|c|c|}
\hline & \multicolumn{4}{|c|}{ Dependent Variables } \\
\hline & \multicolumn{2}{|c|}{ Log of Average Wage } & \multicolumn{2}{|c|}{ Log of Employment } \\
\hline & \multicolumn{4}{|c|}{ Controls for employment-sector distributions } \\
\hline $\begin{array}{l}\text { Empirical tax rate } \\
\text { (tax bill/total wage bill) }\end{array}$ & \multirow[t]{2}{*}{$\begin{array}{l}-1.200 \\
{[0.194]^{\star * *}}\end{array}$} & & \multirow[t]{2}{*}{$\begin{array}{l}0.380 \\
{[0.406}\end{array}$} & \\
\hline Legal tax rate & & $\begin{array}{l}-0.644 \\
{[0.151]^{\star * *}}\end{array}$ & & $\begin{array}{l}0.456 \\
{[0.410]}\end{array}$ \\
\hline R2 within & 0.93 & 0.92 & 0.60 & 0.60 \\
\hline R2 between & 0.38 & 0.40 & 0.03 & 0.02 \\
\hline \multirow[t]{2}{*}{ R2 overall } & 0.47 & 0.47 & 0.01 & 0.01 \\
\hline & \multicolumn{4}{|c|}{$\begin{array}{l}\text { Controls for employment-sector distributions and full interactions between } \\
\text { time period and indicators for } 10 \text { groups ordered by employment level }\end{array}$} \\
\hline $\begin{array}{l}\text { Empirical tax rate } \\
\text { (tax bill/total wage bill) }\end{array}$ & $\begin{array}{l}-1.458 \\
{[0.271]^{\star * *}}\end{array}$ & & $\begin{array}{l}0.122 \\
{[0.582}\end{array}$ & \\
\hline Legal tax rate & & $\begin{array}{l}-0.742 \\
{[0.254]^{\star * *}}\end{array}$ & & $\begin{array}{l}0.223 \\
{[0.661]}\end{array}$ \\
\hline R2 within & 0.94 & 0.94 & 0.68 & 0.68 \\
\hline R2 between & 0.29 & 0.32 & 0.03 & 0.02 \\
\hline \multirow{2}{*}{ R2 overall } & 0.44 & 0.45 & 0.02 & 0.01 \\
\hline & \multicolumn{4}{|c|}{$\begin{array}{l}\text { Controls for employment-sector distributions and full interactions between } \\
\text { time period and indicators for } 10 \text { groups ordered by average wage }\end{array}$} \\
\hline $\begin{array}{l}\text { Empirical tax rate } \\
\text { (tax bill/total wage bill) }\end{array}$ & $\begin{array}{l}-1.347 \\
{[0.190]^{\star * *}}\end{array}$ & & $\begin{array}{l}0.532 \\
{[0.496}\end{array}$ & \\
\hline Legal tax rate & & $\begin{array}{l}-0.957 \\
{[0.191]^{\star \star *}}\end{array}$ & & $\begin{array}{l}0.777 \\
{[0.538]}\end{array}$ \\
\hline R2 within & 0.94 & 0.94 & 0.69 & 0.69 \\
\hline R2 between & 0.27 & 0.20 & 0.08 & 0.05 \\
\hline \multirow[t]{2}{*}{ R2 overall } & 0.45 & 0.41 & 0.05 & 0.03 \\
\hline & \multicolumn{4}{|c|}{$\begin{array}{l}\text { Controls for employment-sector distributions and full interactions between } \\
\text { time period and indicators for } 3 \text { regional groupings (North, Center and South) }\end{array}$} \\
\hline $\begin{array}{l}\text { Empirical tax rate } \\
\text { (tax bill/total wage bill) }\end{array}$ & $\begin{array}{l}-1.315 \\
{[0.290]^{\star \star *}}\end{array}$ & & $\begin{array}{l}-0.124 \\
{[0.475}\end{array}$ & \\
\hline Legal tax rate & & $\begin{array}{l}-0.542 \\
{[0.303]^{\star}}\end{array}$ & & $\begin{array}{l}-0.102 \\
{[0.588]}\end{array}$ \\
\hline R2 within & 0.93 & 0.93 & 0.63 & 0.63 \\
\hline R2 between & 0.23 & 0.30 & 0.09 & 0.09 \\
\hline R2 overall & 0.41 & 0.43 & 0.04 & 0.05 \\
\hline Observations & \multicolumn{4}{|c|}{4018} \\
\hline Number of areas & & & & \\
\hline
\end{tabular}

Note: * significant at 10 percent; ${ }^{* *}$ significant at 5 percent; ${ }^{* *}$ significant at 1 percent. All regressions include 49 area and 82 month fixed effects, and controls for the proportion of employment in each of 19 sectoral categories at every time period in each area. Standard errors are clustered the area level. 
The interactions between time effects and groups defined by levels of the dependent variables (wages and employment) address the concern that the results in Table 4 might follow from a spurious correlation between changes in taxes and differential trends by area, which would not be captured by the area fixed effects. The rationale is that larger (or richer) areas might share different shocks from those of smaller (or poorer) areas, while the former experienced lower tax reductions than the latter. Including time controls interacted with groups defined by the level of the dependent variables helps ruling out spurious correlation in the previous results. This procedure is akin to allowing for different slopes by the level of the intercept in simple difference in differences models.

The results for the employment-level and wage-group trends are similar to those obtained in Table 4 and in the first panel of Table 5: the coefficients for the wage regressions are negative and highly significant, while those for the employment regressions are not statistically different from zero. The fact that the results are still significant after the introduction of these controls indicates that the results are not driven by spurious correlation caused by differential trends or shocks. The coefficients for the wage regressions, however, are now even higher in absolute terms: they are well above 1 for the empirical tax rate, and for the legal rate they are much closer to 1 than in Table 4, especially when wage-group trends are included. With employment sizetime controls and region-time controls, however, the coefficient of the legal tax rate indicates less than full shifting.

Finally, Table 6 provides a breakdown of the main results according to the different stages of tax changes defined in the previous section. The top panel presents the results for the tax reduction episodes (March 1995-June 2000), while the bottom panel displays the estimates derived from the model in Equations (3) and (4) for the tax increase only (July 2000-December 2001). There are two noteworthy facts regarding these additional results. First, only the coefficients of the wage equations for the tax reduction episode are significant, with the same pattern as before: the coefficients for the empirical tax rates are higher, in absolute value, than those for the legal rate. Second, the significant coefficients appear to be higher, in absolute value, than those shown in Tables 4 and 5 . 
On the other hand, none of the coefficients seem to be significantly different from zero for the estimations limited to the tax increase period (starting in July 2000, one calendar year before the increase to December 2001). It should be noted, however, that the increase to a common national payroll tax rate was implemented in mid-2001. There is only about half a year's worth of data with the new rate, which greatly reduces the statistical power of this analysis.

Table 6: Results by period

\begin{tabular}{|c|c|c|c|c|}
\hline & \multicolumn{4}{|c|}{ Dependent Variables } \\
\hline & \multicolumn{2}{|c|}{$\begin{array}{c}\text { Log of Average } \\
\text { Wage }\end{array}$} & \multicolumn{2}{|c|}{ Log of Employment } \\
\hline & \multicolumn{4}{|c|}{ Periods 1 and 2 (tax cuts) } \\
\hline $\begin{array}{l}\text { Empirical tax rate } \\
\text { (tax bill/total wage bill) }\end{array}$ & $\begin{array}{l}-1.957 \\
{[0.313]^{\star * *}}\end{array}$ & & $\begin{array}{l}-0.780 \\
{[0.499]}\end{array}$ & \\
\hline Legal tax rate & & $\begin{array}{l}-1.232 \\
{[0.306]^{\star * *}}\end{array}$ & & $\begin{array}{l}-0.772 \\
{[0.748]}\end{array}$ \\
\hline R2 within & 0.91 & 0.91 & 0.44 & 0.44 \\
\hline R2 between & 0.04 & 0.10 & 0.45 & 0.51 \\
\hline R2 overall & 0.25 & 0.25 & 0.03 & 0.02 \\
\hline \multirow[t]{2}{*}{ Observations } & \multicolumn{4}{|c|}{3136} \\
\hline & \multicolumn{4}{|c|}{ Period 3 (tax increase) } \\
\hline $\begin{array}{l}\text { Empirical tax rate } \\
\text { (tax bill/total wage bill) }\end{array}$ & $\begin{array}{l}-0.269 \\
{[0.222]}\end{array}$ & & $\begin{array}{l}0.033 \\
{[0.128]}\end{array}$ & \\
\hline Legal tax rate & & $\begin{array}{l}0.195 \\
{[0.179]}\end{array}$ & & $\begin{array}{l}0.001 \\
{[0.095]}\end{array}$ \\
\hline R2 within & 0.91 & 0.91 & 0.44 & 0.44 \\
\hline R2 between & 0.04 & 0.10 & 0.45 & 0.51 \\
\hline R2 overall & 0.25 & 0.25 & 0.03 & 0.02 \\
\hline Observations & \multicolumn{4}{|c|}{882} \\
\hline Number of areas & \multicolumn{4}{|c|}{49} \\
\hline
\end{tabular}

Note: * significant at $10 \% ;{ }^{* *}$ significant at 5 percent; ${ }^{* * *}$ significant at 1 percent. All regressions include 49 area and 82 month fixed effects, and controls for the proportion of employment in each of 19 sectoral categories at every time period in each area. Standard errors are clustered at the area level. 


\section{Discussion and conclusions}

This paper studied the relationship among payroll taxes, wages and employment by focusing on geographical variations in policy changes in Argentina. A distinguishing feature of this study is the availability of exact geographic-specific tax rates. The results indicate that a significant measurement error is carried over from the dependent variable (average wages) to the tax rates constructed by dividing tax payments by wages. The resulting coefficients in this study are roughly twice as high when using constructed rather than legal tax rates. Once this bias is accounted for, the results indicate that changes in payroll tax rates are only partially shifted onto wages, with estimates ranging between 0.4 and 0.9 percent per percentage-point reduction in the tax rate. They also point to the absence of any significant effect on employment (see Gruber, 1997 and Nickell and Layard, 1999).

The period under study includes reductions and increases in payroll tax rates. When these episodes are analyzed separately, the results indicate that only reductions in taxes have a significant impact on wages, although the statistical power of this analysis is limited due to the shorter amount of time available in the data after the tax increase.

The presence of full or partial shifting with no employment effects may be explained by a combination of steep (inelastic) labor demand and supply functions, which result in large price effects and negligible quantity changes (Blundell and MaCurdy, 1999). These implied elasticities might result from the limited mobility of the labor force and the regional structure of the labor market in Argentina, since workers do not seem to react to changes in wages. ${ }^{23}$ Regional labor mobility is limited in Argentina: as noted by Galiani and Nickell (1999), the rate of migration is 1 percent per year compared to 3 percent in the U.S. Regional migration is driven mostly by wage differentials, and it can be hampered by transaction costs. These transaction costs are higher in developing countries: there is limited availability of rental housing (because of lower enforcement of property rights), and credit scarcity restricts the mortgage market. Moreover, the Center and South of the country have had significantly higher wages and standards of living than the North, and these wage differentials have become strong pull factors for workers at least since the 1960s. These differences in levels are very large, and dominate any wedge that might be

\footnotetext{
${ }^{23}$ This point was suggested by an anonymous reviewer.
} 
introduced by differential changes in regional tax rates. While the explanation of inelastic supply and demand is consistent with competitive models of wage determination, the presence of shifting only when taxes are reduced might also be indicative of the presence of downward wage rigidity.

The main argument justifying the tax cuts introduced in 1995-1999 in Argentina (namely, that lower labor costs would increase employment) was not borne out by events. The wage gains, though significant (with estimates ranging between 0.4 and 0.9 percent per percentage-point reduction in the tax rate), are relatively minor when compared to the historical fluctuations of real wages in Argentina (Galiani and Gerchunoff, 2003). However, the tax cuts did have a significant effect on Government finance: payroll tax collection as a percentage of total wage income (considering the whole country, but excluding public sector and agricultural workers) fell by almost half from the mid 1990s to the early 2000s. 


\section{Bibliography}

AFIP (2006), SIAP: Sistema Integrado de Aplicaciones, electronic software, available at http://www.afip.gov.ar/programas/siap_main.asp. Administración Federal de Ingresos Públicos, Argentina.

Anderson, Patricia M., and Bruce D. Meyer (1997), "The effects of firm specific taxes and government mandates with an application to the unemployment insurance program", Journal of Public Economics 65 (2), 119-145.

Angrist, J. and Pischke, J. (2008), Mostly Harmless Econometrics, Princeton University Press.

Besley, T. and R. Burgess (2004), "Can Labor Regulation Hinder Economic Performance? Evidence from India”, Quarterly Journal of Economics 119, No. 1 (2004), pp. 91-134.

Blundell, R., and T. MaCurdy (1999), "Labor supply: A review of alternative approaches," Chapter 27 of Ashenfelter, O. and D. Card (eds.), Handbook of Labor Economics, edition 1, volume 3, pages 1559-1695, Elsevier.

Brittain, John A. (1971), "The incidence of social security payroll taxes", American Economic Review 61 (1), 110-125.

Dolado, J., F. Kramarz, S. Machin, A. Manning, D. Margolis and C. Teulings (1996), "The Economic Impact of Minimum Wages in Europe", Economic Policy, 23, pp. 317-372.

Galiani, S. and Nickell, S. (1999), "Unemployment in Argentina in the 1990s”, WP 218, Instituto Torcuato Di Tella.

Galiani , S. and P. Gerchunoff (2003), "The labor market”, Chapter 6 in della Paolera, G. and A. Taylor (eds.), A New Economic History of Argentina, New York: Cambridge University Press, 2003.

Gruber, J. (1997), “The Incidence of Payroll Taxation: Evidence from Chile”, Journal of Labor Economics, vol. 15, No. 3.

Gruber, J. and A. Krueger (1990), "The incidence of mandated employer-provided insurance: lessons from workers' compensation insurance", Working Paper 279, Industrial Relations Section, Princeton University.

Holmlund, B. (1983), "Payroll taxes and wage inflation: the Swedish experience", Scandinavian Journal of Economics, vol. 85, No. 1, pp. 1-15.

Kugler, A. and M. Kugler (2003), "The Labor Market Effects of Payroll Taxes in a MiddleIncome Country: Evidence from Colombia", IZA DP No. 852.

MTSS (1998), El trabajo en la Argentina: la transformación laboral, Ministerio de Trabajo y Seguridad Social, Buenos Aires, Argentina.

Murphy, K. (2007), "The impact of unemployment insurance taxes on wages", Labour Economics 14, pp. 457-484.

Neffa, J. (2005), "Las principales reformas de la relación salarial operadas durante el período 1989-2001 con impactos directos o indirectos sobre el empleo", Materiales de Investigación No. 4, CEIL-PIETTE/CONICET (Centro de Estudios e Investigaciones Laborales, Programa de Tecnología, Investigaciones Económicas sobre Trabajo y Empleo), Buenos Aires, Argentina. With the collaboration of Drs. Eugenio Biafore, Mariano Cardelli and Lic. Sebastián Gioiae. 
Nickell, S. and R. Layard (1999), "Labor market institutions and economic performance", in: Ashenfelter, O. and D. Card (eds.), Handbook of Labor Economics, edition 1, vol. 3, chapter 46, pp. 3029-3084, Elsevier.

StataCorp (2009). "Stata Statistical Software Reference Manual: Release 11”, College Station, TX: StataCorp LP.

Summers, L. (1989), "Some simple economics of mandated benefits", American Economic Association Papers and Proceedings 79(2), pp. 117-183. 


\section{Appendix: Legal tax rates}

Screen capture of the standardized tax returns software listing areas and tax rates by date

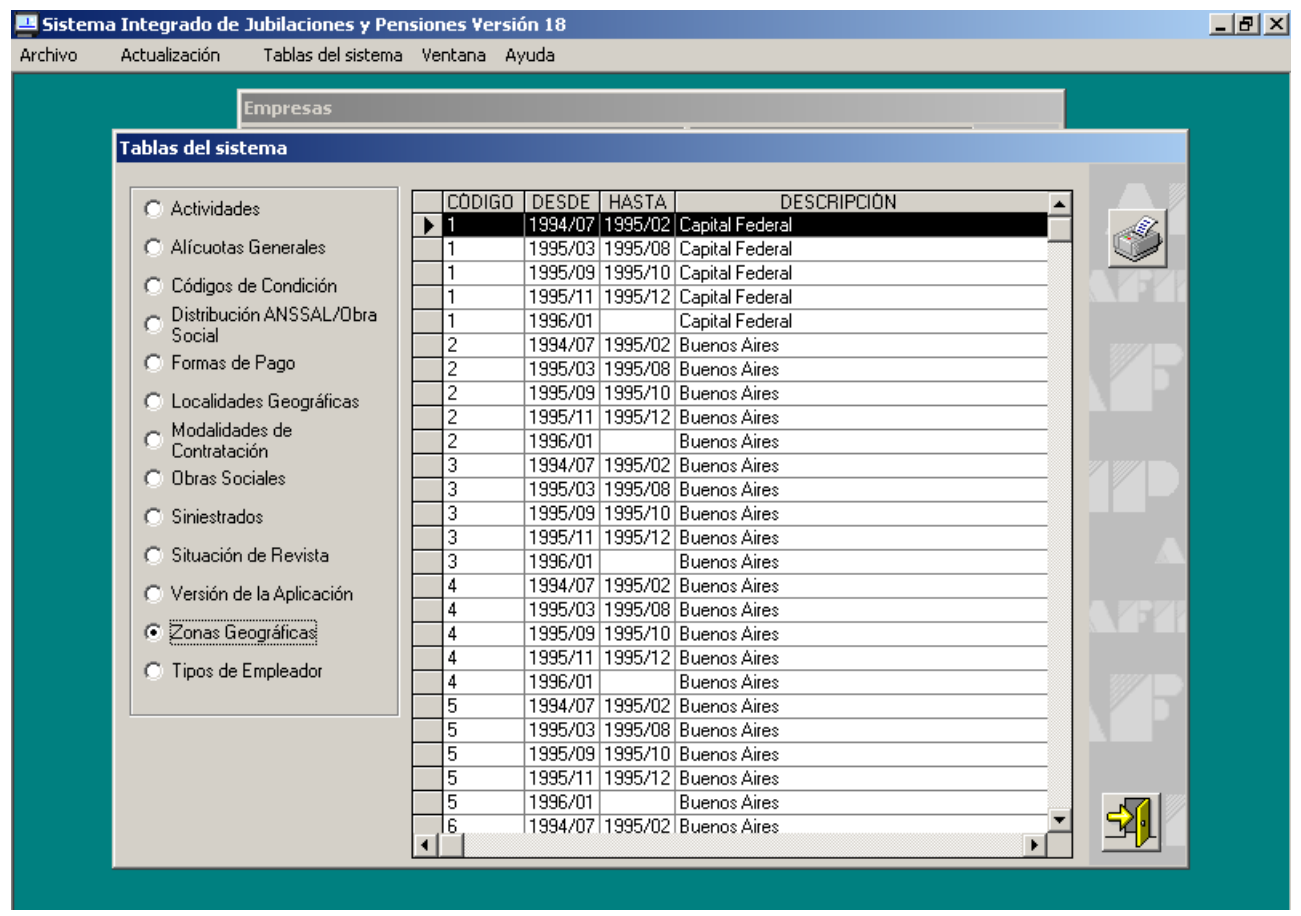

Screen capture of the standardized tax returns software listing areas and tax reduction coefficients

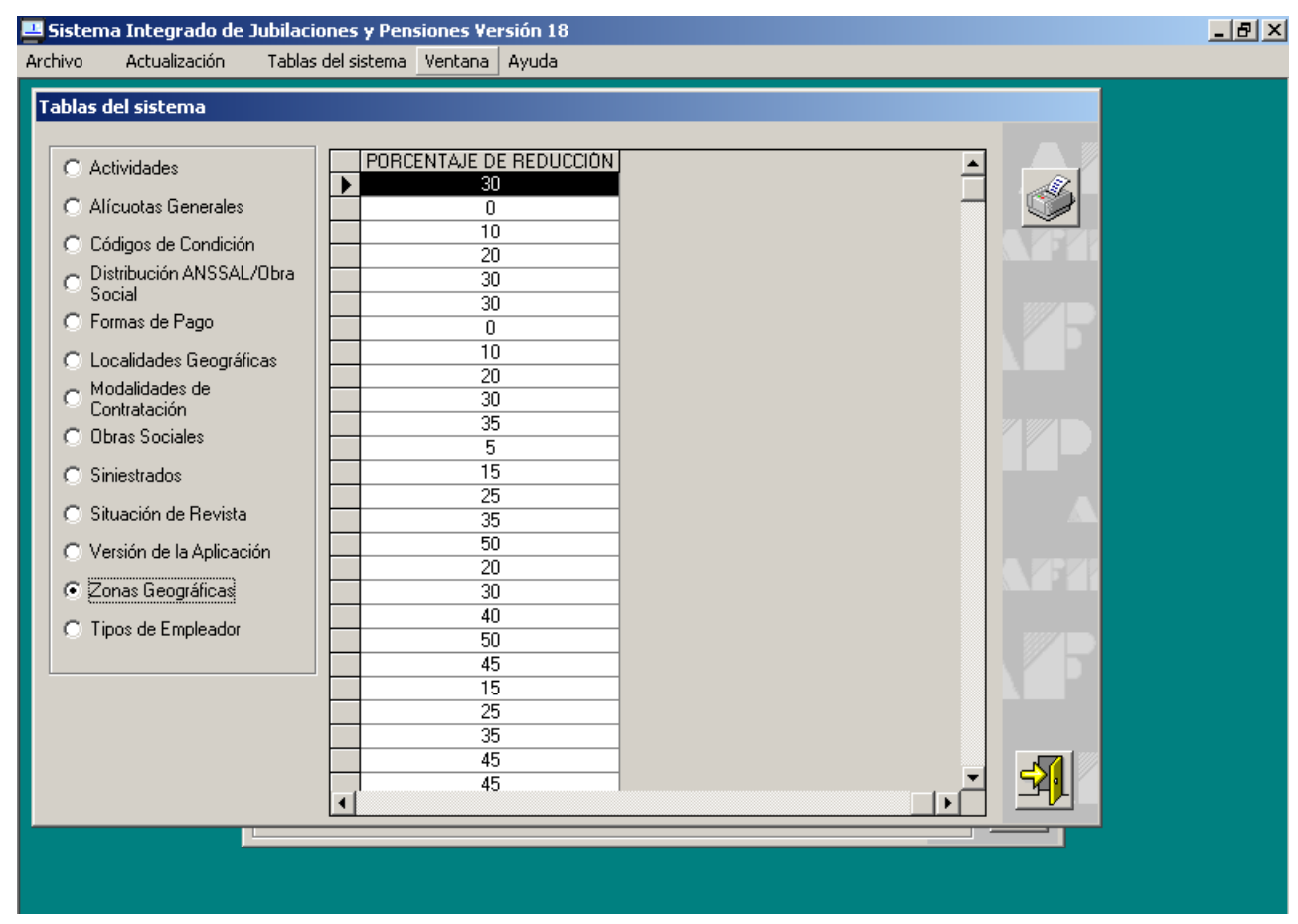


Screen capture of the standardized tax returns software showing the fixed nature of the area entry

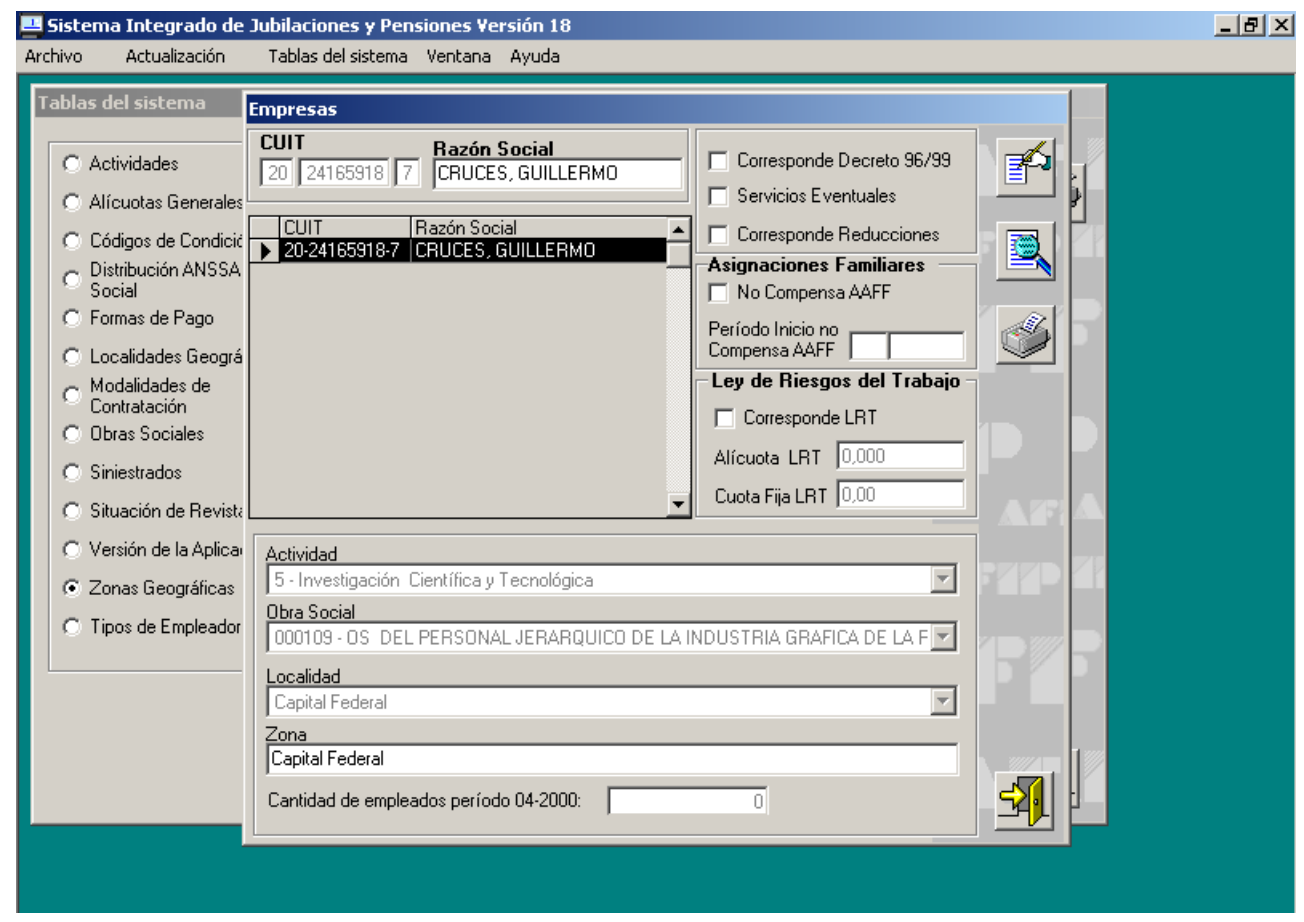




\section{Printout of the standardized tax returns software tax reduction coefficient tables}

Fecha:04/08/2009 NPIP

Tabla 14 - Zonas Geográficas

\begin{tabular}{|c|c|c|c|c|}
\hline Código & Vigencia Desde & Vigencia Hasta & Descripción & Porcentaje de Reducción \\
\hline 1 & $1994 / 07$ & 1995/02 & Capital Federal & 30 \\
\hline 1 & $1995 / 03$ & $1995 / 08$ & Capital Federal & 0 \\
\hline 1 & 1995/09 & $1995 / 10$ & Capital Federal & 10 \\
\hline 1 & 1995/11 & $1995 / 12$ & Capital Federal & 20 \\
\hline 1 & 1996/01 & & Capital Federal & 30 \\
\hline 2 & $1994 / 07$ & $1995 / 02$ & Buenos Aires & 30 \\
\hline 2 & $1995 / 03$ & $1995 / 08$ & Buenos Aires & 0 \\
\hline 2 & 1995/09 & $1995 / 10$ & Buenos Aires & 10 \\
\hline 2 & $1995 / 11$ & $1995 / 12$ & Buenos Aires & 20 \\
\hline 2 & 1996/01 & & Buenos Aires & 30 \\
\hline 3 & $1994 / 07$ & $1995 / 02$ & Buenos Aires & 35 \\
\hline 3 & $1995 / 03$ & $1995 / 08$ & Buenos Aires & 5 \\
\hline 3 & $1995 / 09$ & $1995 / 10$ & Buenos Aires & 15 \\
\hline 3 & $1995 / 11$ & $1995 / 12$ & Buenos Aires & 25 \\
\hline 3 & 1996/01 & & Buenos Aires & 35 \\
\hline 4 & $1994 / 07$ & $1995 / 02$ & Buenos Aires & 50 \\
\hline 4 & $1995 / 03$ & $1995 / 08$ & Buenos Aires & 20 \\
\hline 4 & 1995/09 & $1995 / 10$ & Buenos Aires & 30 \\
\hline 4 & $1995 / 11$ & $1995 / 12$ & Buenos Aires & 40 \\
\hline 4 & $1996 / 01$ & & Buenos Aires & 50 \\
\hline 5 & $1994 / 07$ & 1995/02 & Buenos Aires & 45 \\
\hline 5 & $1995 / 03$ & 1995/08 & Buenos Aires & 15 \\
\hline 5 & 1995/09 & $1995 / 10$ & Buenos Aires & 25 \\
\hline 5 & 1995/11 & $1995 / 12$ & Buenos Aires & 35 \\
\hline 5 & 1996/01 & & Buenos Aires & 45 \\
\hline 6 & $1994 / 07$ & $1995 / 02$ & Buenos Aires & 45 \\
\hline 6 & $1995 / 03$ & 1995/08 & Buenos Aires & 15 \\
\hline 6 & 1995/09 & $1995 / 10$ & Buenos Aires & 25 \\
\hline 6 & 1995/11 & $1995 / 12$ & Buenos Aires & 35 \\
\hline 6 & 1996/01 & & Buenos Aires & 45 \\
\hline 7 & $1994 / 07$ & 1995/02 & Buenos Aires & 40 \\
\hline 7 & $1995 / 03$ & $1995 / 08$ & Buenos Aires & 10 \\
\hline 7 & $1995 / 09$ & $1995 / 10$ & Buenos Aires & 20 \\
\hline
\end{tabular}

\begin{tabular}{|c|c|c|c|c|}
\hline 7 & 1995/11 & $1995 / 12$ & Buenos Aires & 30 \\
\hline 7 & $1996 / 01$ & & Buenos Aires & 40 \\
\hline 8 & $1994 / 07$ & $1995 / 02$ & Catamarca & 60 \\
\hline 8 & $1995 / 03$ & $1995 / 08$ & Catamarca & 30 \\
\hline 8 & $1995 / 09$ & $1995 / 10$ & Catamarca & 40 \\
\hline 8 & $1995 / 11$ & $1995 / 12$ & Catamarca & 50 \\
\hline 8 & 1996/01 & & Catamarca & 60 \\
\hline 9 & 1994/07 & $1995 / 02$ & Catamarca & 65 \\
\hline 9 & $1995 / 03$ & $1995 / 08$ & Catamarca & 35 \\
\hline 9 & $1995 / 09$ & $1995 / 10$ & Catamarca & 45 \\
\hline 9 & $1995 / 11$ & $1995 / 12$ & Catamarca & 55 \\
\hline 9 & $1996 / 01$ & & Catamarca & 65 \\
\hline 10 & $1994 / 07$ & $1995 / 02$ & Cordoba & 60 \\
\hline 10 & $1995 / 03$ & $1995 / 08$ & Cordoba & 30 \\
\hline 10 & 1995/09 & $1995 / 10$ & Cordoba & 40 \\
\hline 10 & 1995/11 & $1995 / 12$ & Cordoba & 50 \\
\hline 10 & $1996 / 01$ & & Cordoba & 60 \\
\hline 11 & $1994 / 07$ & $1995 / 02$ & Cordoba & 60 \\
\hline 11 & $1995 / 03$ & $1995 / 08$ & Cordoba & 30 \\
\hline 11 & $1995 / 09$ & $1995 / 10$ & Cordoba & 40 \\
\hline 11 & $1995 / 11$ & $1995 / 12$ & Cordoba & 50 \\
\hline 11 & $1996 / 01$ & & Cordoba & 60 \\
\hline 12 & $1994 / 07$ & $1995 / 02$ & Cordoba & 60 \\
\hline 12 & $1995 / 03$ & $1995 / 08$ & Cordoba & 30 \\
\hline 12 & 1995/09 & $1995 / 10$ & Cordoba & 40 \\
\hline 12 & $1995 / 11$ & $1995 / 12$ & Cordoba & 50 \\
\hline 12 & $1996 / 01$ & & Cordoba & 60 \\
\hline 13 & $1994 / 07$ & $1995 / 02$ & Cordoba & 55 \\
\hline 13 & 1995/03 & $1995 / 08$ & Cordoba & 25 \\
\hline 13 & $1995 / 09$ & $1995 / 10$ & Cordoba & 35 \\
\hline 13 & $1995 / 11$ & $1995 / 12$ & Cordoba & 45 \\
\hline 13 & $1996 / 01$ & & Cordoba & 55 \\
\hline 14 & $1994 / 07$ & $1995 / 02$ & Cordoba & 55 \\
\hline 14 & $1995 / 03$ & $1995 / 08$ & Cordoba & 25 \\
\hline 14 & $1995 / 09$ & $1995 / 10$ & Cordoba & 35 \\
\hline 14 & $1995 / 11$ & $1995 / 12$ & Cordoba & 45 \\
\hline 14 & 1996/01 & & Cordoba & 55 \\
\hline 15 & $1994 / 07$ & $1995 / 02$ & Cordoba & 55 \\
\hline 15 & $1995 / 03$ & $1995 / 08$ & Cordoba & 25 \\
\hline 15 & 1995/09 & $1995 / 10$ & Cordoba & 35 \\
\hline 15 & $1995 / 11$ & $1995 / 12$ & Cordoba & 45 \\
\hline 15 & 1996/01 & & Cordoba & 55 \\
\hline 16 & $1994 / 07$ & $1995 / 02$ & Cordoba & 55 \\
\hline 16 & $1995 / 03$ & $1995 / 08$ & Cordoba & 25 \\
\hline 16 & $1995 / 09$ & $1995 / 10$ & Cordoba & 35 \\
\hline
\end{tabular}




\begin{tabular}{|c|c|c|c|}
\hline 16 & 1995/11 & $1995 / 12$ & Cordoba \\
\hline 16 & $1996 / 01$ & & Cordoba \\
\hline 17 & 1994/07 & $1995 / 02$ & Cordoba \\
\hline 17 & $1995 / 03$ & $1995 / 08$ & Cordoba \\
\hline 17 & $1995 / 09$ & $1995 / 10$ & Cordoba \\
\hline 17 & $1995 / 11$ & $1995 / 12$ & Cordoba \\
\hline 17 & $1996 / 01$ & & Cordoba \\
\hline 18 & 1994/07 & $1995 / 02$ & Cordoba \\
\hline 18 & $1995 / 03$ & $1995 / 08$ & Cordoba \\
\hline 18 & 1995/09 & $1995 / 10$ & Cordoba \\
\hline 18 & 1995/11 & $1995 / 12$ & Cordoba \\
\hline 18 & 1996/01 & & Cordoba \\
\hline 19 & $1994 / 07$ & $1995 / 02$ & Cordoba \\
\hline 19 & $1995 / 03$ & $1995 / 08$ & Cordoba \\
\hline 19 & $1995 / 09$ & $1995 / 10$ & Cordoba \\
\hline 19 & 1995/11 & $1995 / 12$ & Cordoba \\
\hline 19 & 1996/01 & & Cordoba \\
\hline 20 & $1994 / 07$ & $1995 / 02$ & Corrientes \\
\hline 20 & $1995 / 03$ & $1995 / 08$ & Corrientes \\
\hline 20 & $1995 / 09$ & $1995 / 10$ & Corrientes \\
\hline 20 & $1995 / 11$ & $1995 / 12$ & Corrientes \\
\hline 20 & $1996 / 01$ & & Corrientes \\
\hline 21 & 1994/07 & $1995 / 02$ & Corrientes \\
\hline 21 & $1995 / 03$ & $1995 / 08$ & Corrientes \\
\hline 21 & $1995 / 09$ & $1995 / 10$ & Corrientes \\
\hline 21 & $1995 / 11$ & $1995 / 12$ & Corrientes \\
\hline 21 & 1996/01 & & Corrientes \\
\hline 22 & $1994 / 07$ & $1995 / 02$ & Corrientes \\
\hline 22 & $1995 / 03$ & $1995 / 08$ & Corrientes \\
\hline 22 & $1995 / 09$ & $1995 / 10$ & Corrientes \\
\hline 22 & 1995/11 & $1995 / 12$ & Corrientes \\
\hline 22 & 1996/01 & & Corrientes \\
\hline 23 & 1994/07 & $1995 / 02$ & Corrientes \\
\hline 23 & $1995 / 03$ & $1995 / 08$ & Corrientes \\
\hline 23 & $1995 / 09$ & $1995 / 10$ & Corrientes \\
\hline 23 & $1995 / 11$ & $1995 / 12$ & Corrientes \\
\hline 23 & 1996/01 & & Corrientes \\
\hline 24 & 1994/07 & $1995 / 02$ & Corrientes \\
\hline 24 & $1995 / 03$ & $1995 / 08$ & Corrientes \\
\hline 24 & 1995/09 & $1995 / 10$ & Corrientes \\
\hline 24 & 1995/11 & $1995 / 12$ & Corrientes \\
\hline 24 & 1996/01 & & Corrientes \\
\hline 25 & $1994 / 07$ & $1995 / 02$ & Corrientes \\
\hline 25 & $1995 / 03$ & $1995 / 08$ & Corrientes \\
\hline 25 & 1995/09 & $1995 / 10$ & Corrientes \\
\hline
\end{tabular}

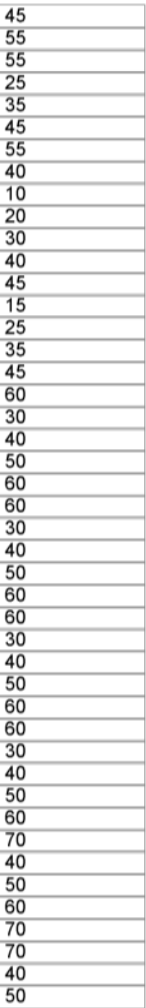

Página

\begin{tabular}{|c|c|c|c|c|}
\hline 25 & 1995/11 & $1995 / 12$ & Corrientes & 60 \\
\hline 25 & $1996 / 01$ & & Corrientes & 70 \\
\hline 26 & $1994 / 07$ & $1995 / 02$ & Chaco & 70 \\
\hline 26 & $1995 / 03$ & $1995 / 08$ & Chaco & 40 \\
\hline 26 & $1995 / 09$ & $1995 / 10$ & Chaco & 50 \\
\hline 26 & $1995 / 11$ & $1995 / 12$ & Chaco & 60 \\
\hline 26 & $1996 / 01$ & & Chaco & 70 \\
\hline 27 & $1994 / 07$ & $1995 / 02$ & Chaco & 80 \\
\hline 27 & $1995 / 03$ & $1995 / 08$ & Chaco & 50 \\
\hline 27 & $1995 / 09$ & $1995 / 10$ & Chaco & 60 \\
\hline 27 & $1995 / 11$ & $1995 / 12$ & Chaco & 70 \\
\hline 27 & 1996/01 & & Chaco & 80 \\
\hline 28 & $1994 / 07$ & $1995 / 02$ & Chubut & 60 \\
\hline 28 & 1995/03 & $1995 / 08$ & Chubut & 30 \\
\hline 28 & $1995 / 09$ & $1995 / 10$ & Chubut & 40 \\
\hline 28 & $1995 / 11$ & $1995 / 12$ & Chubut & 50 \\
\hline 28 & $1996 / 01$ & & Chubut & 60 \\
\hline 29 & $1994 / 07$ & $1995 / 02$ & Chubut & 65 \\
\hline 29 & $1995 / 03$ & $1995 / 08$ & Chubut & 35 \\
\hline 29 & $1995 / 09$ & $1995 / 10$ & Chubut & 45 \\
\hline 29 & 1995/11 & $1995 / 12$ & Chubut & 55 \\
\hline 29 & $1996 / 01$ & & Chubut & 65 \\
\hline 30 & $1994 / 07$ & $1995 / 02$ & Entre Ríos & 60 \\
\hline 30 & $1995 / 03$ & $1995 / 08$ & Entre Rios & 30 \\
\hline 30 & $1995 / 09$ & $1995 / 10$ & Entre Rios & 40 \\
\hline 30 & $1995 / 11$ & $1995 / 12$ & Entre Rios & 50 \\
\hline 30 & $1996 / 01$ & & Entre Rios & 60 \\
\hline 31 & $1994 / 07$ & $1995 / 02$ & Entre Rios & 60 \\
\hline 31 & $1995 / 03$ & $1995 / 08$ & Entre Rios & 30 \\
\hline 31 & $1995 / 09$ & $1995 / 10$ & Entre Ríos & 40 \\
\hline 31 & $1995 / 11$ & $1995 / 12$ & Entre Rios & 50 \\
\hline 31 & $1996 / 01$ & & Entre Rios & 60 \\
\hline 32 & $1994 / 07$ & $1995 / 02$ & Entre Rios & 45 \\
\hline 32 & $1995 / 03$ & $1995 / 08$ & Entre Rios & 15 \\
\hline 32 & $1995 / 09$ & $1995 / 10$ & Entre Rios & 25 \\
\hline 32 & $1995 / 11$ & $1995 / 12$ & Entre Rios & 35 \\
\hline 32 & 1996/01 & & Entre Rios & 45 \\
\hline 33 & $1994 / 07$ & $1995 / 02$ & Entre Rios & 50 \\
\hline 33 & $1995 / 03$ & $1995 / 08$ & Entre Rios & 20 \\
\hline 33 & $1995 / 09$ & $1995 / 10$ & Entre Ríos & 30 \\
\hline 33 & $1995 / 11$ & $1995 / 12$ & Entre Rios & 40 \\
\hline 33 & $1996 / 01$ & & Entre Rios & 50 \\
\hline 34 & $1994 / 07$ & $1995 / 02$ & Formosa & 75 \\
\hline 34 & $1995 / 03$ & $1995 / 08$ & Formosa & 45 \\
\hline 34 & $1995 / 09$ & $1995 / 10$ & Formosa & 55 \\
\hline
\end{tabular}

Página 4 


\begin{tabular}{|c|c|c|c|c|}
\hline 34 & 1995/11 & $1995 / 12$ & Formosa & 65 \\
\hline 34 & $1996 / 01$ & & Formosa & 75 \\
\hline 35 & $1994 / 07$ & $1995 / 02$ & Formosa & 80 \\
\hline 35 & 1995/03 & 1995/08 & Formosa & 50 \\
\hline 35 & 1995/09 & $1995 / 10$ & Formosa & 60 \\
\hline 35 & $1995 / 11$ & $1995 / 12$ & Formosa & 70 \\
\hline 35 & $1996 / 01$ & & Formosa & 80 \\
\hline 36 & $1994 / 07$ & $1995 / 02$ & Jujuy & 70 \\
\hline 36 & 1995/03 & $1995 / 08$ & Jujuy & 40 \\
\hline 36 & 1995/09 & $1995 / 10$ & Jujuy & 50 \\
\hline 36 & 1995/11 & $1995 / 12$ & Jujuy & 60 \\
\hline 36 & 1996/01 & & Jujuy & 70 \\
\hline 37 & $1994 / 07$ & $1995 / 02$ & Jujuy & 75 \\
\hline 37 & $1995 / 03$ & $1995 / 08$ & Jujuy & 45 \\
\hline 37 & $1995 / 09$ & $1995 / 10$ & Jujuy & 55 \\
\hline 37 & 1995/11 & $1995 / 12$ & Jujuy & 65 \\
\hline 37 & 1996/01 & & Jujuy & 75 \\
\hline 38 & $1994 / 07$ & $1995 / 02$ & La Pampa & 55 \\
\hline 38 & $1995 / 03$ & $1995 / 08$ & La Pampa & 25 \\
\hline 38 & $1995 / 09$ & $1995 / 10$ & La Pampa & 35 \\
\hline 38 & 1995/11 & $1995 / 12$ & La Pampa & 45 \\
\hline 38 & $1996 / 01$ & & La Pampa & 55 \\
\hline 39 & 1994/07 & $1995 / 02$ & La Pampa & 55 \\
\hline 39 & $1995 / 03$ & $1995 / 08$ & La Pampa & 25 \\
\hline 39 & 1995/09 & $1995 / 10$ & La Pampa & 35 \\
\hline 39 & 1995/11 & $1995 / 12$ & La Pampa & 45 \\
\hline 39 & 1996/01 & & La Pampa & 55 \\
\hline 40 & $1994 / 07$ & $1995 / 02$ & La Pampa & 55 \\
\hline 40 & $1995 / 03$ & $1995 / 08$ & La Pampa & 25 \\
\hline 40 & 1995/09 & $1995 / 10$ & La Pampa & 35 \\
\hline 40 & 1995/11 & $1995 / 12$ & La Pampa & 45 \\
\hline 40 & 1996/01 & & La Pampa & 55 \\
\hline 41 & $1994 / 07$ & $1995 / 02$ & La Pampa & 55 \\
\hline 41 & $1995 / 03$ & $1995 / 08$ & La Pampa & 25 \\
\hline 41 & $1995 / 09$ & $1995 / 10$ & La Pampa & 35 \\
\hline 41 & $1995 / 11$ & $1995 / 12$ & La Pampa & 45 \\
\hline 41 & $1996 / 01$ & & La Pampa & 55 \\
\hline 42 & $1994 / 07$ & $1995 / 02$ & La Pampa & 55 \\
\hline 42 & $1995 / 03$ & $1995 / 08$ & La Pampa & 25 \\
\hline 42 & 1995/09 & $1995 / 10$ & La Pampa & 35 \\
\hline 42 & 1995/11 & $1995 / 12$ & La Pampa & 45 \\
\hline 42 & 1996/01 & & La Pampa & 55 \\
\hline 43 & $1994 / 07$ & $1995 / 02$ & La Pampa & 55 \\
\hline 43 & $1995 / 03$ & $1995 / 08$ & La Pampa & 25 \\
\hline 43 & 1995/09 & $1995 / 10$ & La Pampa & 35 \\
\hline
\end{tabular}

Página 5

\begin{tabular}{|c|c|c|c|c|}
\hline 43 & 1995/11 & $1995 / 12$ & La Pampa & 45 \\
\hline 43 & 1996/01 & & La Pampa & 55 \\
\hline 44 & $1994 / 07$ & $1995 / 02$ & La Pampa & 45 \\
\hline 44 & $1995 / 03$ & $1995 / 08$ & La Pampa & 15 \\
\hline 44 & $1995 / 09$ & $1995 / 10$ & La Pampa & 25 \\
\hline 44 & $1995 / 11$ & $1995 / 12$ & La Pampa & 35 \\
\hline 44 & $1996 / 01$ & & La Pampa & 45 \\
\hline 45 & $1994 / 07$ & $1995 / 02$ & La Pampa & 50 \\
\hline 45 & $1995 / 03$ & $1995 / 08$ & La Pampa & 20 \\
\hline 45 & $1995 / 09$ & $1995 / 10$ & La Pampa & 30 \\
\hline 45 & $1995 / 11$ & $1995 / 12$ & La Pampa & 40 \\
\hline 45 & $1996 / 01$ & & La Pampa & 50 \\
\hline 46 & $1994 / 07$ & $1995 / 02$ & La Rioja & 60 \\
\hline 46 & $1995 / 03$ & $1995 / 08$ & La Rioja & 30 \\
\hline 46 & $1995 / 09$ & $1995 / 10$ & La Rioja & 40 \\
\hline 46 & $1995 / 11$ & $1995 / 12$ & La Rioja & 50 \\
\hline 46 & $1996 / 01$ & & La Rioja & 60 \\
\hline 47 & $1994 / 07$ & $1995 / 02$ & La Rioja & 65 \\
\hline 47 & $1995 / 03$ & $1995 / 08$ & La Rioja & 35 \\
\hline 47 & $1995 / 09$ & $1995 / 10$ & La Rioja & 45 \\
\hline 47 & $1995 / 11$ & $1995 / 12$ & La Rioja & 55 \\
\hline 47 & $1996 / 01$ & & La Rioja & 65 \\
\hline 48 & $1994 / 07$ & $1995 / 02$ & Mendoza & 50 \\
\hline 48 & $1995 / 03$ & $1995 / 08$ & Mendoza & 20 \\
\hline 48 & $1995 / 09$ & $1995 / 10$ & Mendoza & 30 \\
\hline 48 & $1995 / 11$ & $1995 / 12$ & Mendoza & 40 \\
\hline 48 & $1996 / 01$ & & Mendoza & 50 \\
\hline 49 & $1994 / 07$ & $1995 / 02$ & Mendoza & 55 \\
\hline 49 & $1995 / 03$ & $1995 / 08$ & Mendoza & 25 \\
\hline 49 & $1995 / 09$ & $1995 / 10$ & Mendoza & 35 \\
\hline 49 & $1995 / 11$ & $1995 / 12$ & Mendoza & 45 \\
\hline 49 & $1996 / 01$ & & Mendoza & 55 \\
\hline 50 & $1994 / 07$ & $1995 / 02$ & Misiones & 70 \\
\hline 50 & $1995 / 03$ & $1995 / 08$ & Misiones & 40 \\
\hline 50 & $1995 / 09$ & $1995 / 10$ & Misiones & 50 \\
\hline 50 & $1995 / 11$ & $1995 / 12$ & Misiones & 60 \\
\hline 50 & $1996 / 01$ & & Misiones & 70 \\
\hline 51 & $1994 / 07$ & $1995 / 02$ & Misiones & 75 \\
\hline 51 & $1995 / 03$ & $1995 / 08$ & Misiones & 45 \\
\hline 51 & $1995 / 09$ & $1995 / 10$ & Misiones & 55 \\
\hline 51 & $1995 / 11$ & $1995 / 12$ & Misiones & 65 \\
\hline 51 & $1996 / 01$ & & Misiones & 75 \\
\hline 52 & $1994 / 07$ & $1995 / 02$ & Neuquén & 50 \\
\hline 52 & $1995 / 03$ & $1995 / 08$ & Neuquén & 20 \\
\hline 52 & $1995 / 09$ & $1995 / 10$ & Neuquén & 30 \\
\hline
\end{tabular}

Página 6 


\begin{tabular}{|c|c|c|c|}
\hline 52 & 1995/11 & $1995 / 12$ & Neuquén \\
\hline 52 & 1996/01 & & Neuquén \\
\hline 53 & 1994/07 & $1995 / 02$ & Neuquén \\
\hline 53 & $1995 / 03$ & $1995 / 08$ & Neuquén \\
\hline 53 & $1995 / 09$ & $1995 / 10$ & Neuquén \\
\hline 53 & $1995 / 11$ & $1995 / 12$ & Neuquén \\
\hline 53 & $1996 / 01$ & & Neuquén \\
\hline 54 & 1994/07 & $1995 / 02$ & Neuquén \\
\hline 54 & $1995 / 03$ & $1995 / 08$ & Neuquén \\
\hline 54 & 1995/09 & $1995 / 10$ & Neuquén \\
\hline 54 & $1995 / 11$ & $1995 / 12$ & Neuquén \\
\hline 54 & 1996/01 & & Neuquén \\
\hline 55 & $1994 / 07$ & $1995 / 02$ & Neuquén \\
\hline 55 & $1995 / 03$ & $1995 / 08$ & Neuquén \\
\hline 55 & $1995 / 09$ & $1995 / 10$ & Neuquén \\
\hline 55 & 1995/11 & $1995 / 12$ & Neuquén \\
\hline 55 & 1996/01 & & Neuquén \\
\hline 56 & $1994 / 07$ & $1995 / 02$ & Neuquén \\
\hline 56 & $1995 / 03$ & $1995 / 08$ & Neuquén \\
\hline 56 & $1995 / 09$ & $1995 / 10$ & Neuquén \\
\hline 56 & $1995 / 11$ & $1995 / 12$ & Neuquén \\
\hline 56 & $1996 / 01$ & & Neuquén \\
\hline 57 & 1994/07 & $1995 / 02$ & Río Negro \\
\hline 57 & $1995 / 03$ & $1995 / 08$ & Río Negro \\
\hline 57 & $1995 / 09$ & $1995 / 10$ & Río Negro \\
\hline 57 & 1995/11 & $1995 / 12$ & Río Negro \\
\hline 57 & 1996/01 & & Río Negro \\
\hline 58 & $1994 / 07$ & $1995 / 02$ & Río Negro \\
\hline 58 & $1995 / 03$ & $1995 / 08$ & Río Negro \\
\hline 58 & $1995 / 09$ & $1995 / 10$ & Río Negro \\
\hline 58 & 1995/11 & $1995 / 12$ & Río Negro \\
\hline 58 & 1996/01 & & Río Negro \\
\hline 59 & 1994/07 & $1995 / 02$ & Río Negro \\
\hline 59 & $1995 / 03$ & $1995 / 08$ & Río Negro \\
\hline 59 & $1995 / 09$ & $1995 / 10$ & Río Negro \\
\hline 59 & $1995 / 11$ & $1995 / 12$ & Río Negro \\
\hline 59 & 1996/01 & & Río Negro \\
\hline 60 & 1994/07 & $1995 / 02$ & Río Negro \\
\hline 60 & $1995 / 03$ & $1995 / 08$ & Río Negro \\
\hline 60 & 1995/09 & $1995 / 10$ & Río Negro \\
\hline 60 & 1995/11 & $1995 / 12$ & Río Negro \\
\hline 60 & 1996/01 & & Río Negro \\
\hline 61 & $1994 / 07$ & $1995 / 02$ & Salta \\
\hline 61 & $1995 / 03$ & $1995 / 08$ & Salta \\
\hline 61 & 1995/09 & $1995 / 10$ & Salta \\
\hline
\end{tabular}

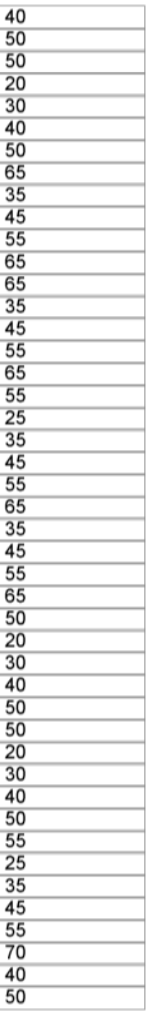

Página

\begin{tabular}{|c|c|c|c|c|}
\hline 61 & 1995/11 & $1995 / 12$ & Salta & 60 \\
\hline 61 & $1996 / 01$ & & Salta & 70 \\
\hline 62 & $1994 / 07$ & $1995 / 02$ & Salta & 75 \\
\hline 62 & $1995 / 03$ & $1995 / 08$ & Salta & 45 \\
\hline 62 & $1995 / 09$ & $1995 / 10$ & Salta & 55 \\
\hline 62 & 1995/11 & $1995 / 12$ & Salta & 65 \\
\hline 62 & $1996 / 01$ & & Salta & 75 \\
\hline 63 & $1994 / 07$ & $1995 / 02$ & San Juan & 55 \\
\hline 63 & $1995 / 03$ & $1995 / 08$ & San Juan & 25 \\
\hline 63 & $1995 / 09$ & $1995 / 10$ & San Juan & 35 \\
\hline 63 & $1995 / 11$ & $1995 / 12$ & San Juan & 45 \\
\hline 63 & $1996 / 01$ & & San Juan & 55 \\
\hline 64 & $1994 / 07$ & $1995 / 02$ & San Juan & 60 \\
\hline 64 & $1995 / 03$ & $1995 / 08$ & San Juan & 30 \\
\hline 64 & $1995 / 09$ & $1995 / 10$ & San Juan & 40 \\
\hline 64 & $1995 / 11$ & $1995 / 12$ & San Juan & 50 \\
\hline 64 & $1996 / 01$ & & San Juan & 60 \\
\hline 65 & $1994 / 07$ & $1995 / 02$ & San Luis & 50 \\
\hline 65 & 1995/03 & $1995 / 08$ & San Luis & 20 \\
\hline 65 & $1995 / 09$ & $1995 / 10$ & San Luis & 30 \\
\hline 65 & $1995 / 11$ & $1995 / 12$ & San Luis & 40 \\
\hline 65 & $1996 / 01$ & & San Luis & 50 \\
\hline 66 & $1994 / 07$ & $1995 / 02$ & San Luis & 55 \\
\hline 66 & $1995 / 03$ & $1995 / 08$ & San Luis & 25 \\
\hline 66 & $1995 / 09$ & $1995 / 10$ & San Luis & 35 \\
\hline 66 & $1995 / 11$ & $1995 / 12$ & San Luis & 45 \\
\hline 66 & $1996 / 01$ & & San Luis & 55 \\
\hline 67 & $1994 / 07$ & $1995 / 02$ & Santa Cruz & 65 \\
\hline 67 & $1995 / 03$ & $1995 / 08$ & Santa Cruz & 35 \\
\hline 67 & $1995 / 09$ & $1995 / 10$ & Santa Cruz & 45 \\
\hline 67 & $1995 / 11$ & $1995 / 12$ & Santa Cruz & 55 \\
\hline 67 & $1996 / 01$ & & Santa Cruz & 65 \\
\hline 68 & $1994 / 07$ & $1995 / 02$ & Santa Cruz & 65 \\
\hline 68 & $1995 / 03$ & $1995 / 08$ & Santa Cruz & 35 \\
\hline 68 & $1995 / 09$ & $1995 / 10$ & Santa Cruz & 45 \\
\hline 68 & $1995 / 11$ & $1995 / 12$ & Santa Cruz & 55 \\
\hline 68 & $1996 / 01$ & & Santa Cruz & 65 \\
\hline 69 & $1994 / 07$ & $1995 / 02$ & Santa Cruz & 70 \\
\hline 69 & $1995 / 03$ & $1995 / 08$ & Santa Cruz & 40 \\
\hline 69 & $1995 / 09$ & $1995 / 10$ & Santa Cruz & 50 \\
\hline 69 & $1995 / 11$ & $1995 / 12$ & Santa Cruz & 60 \\
\hline 69 & $1996 / 01$ & & Santa Cruz & 70 \\
\hline 70 & $1994 / 07$ & $1995 / 02$ & Santa Fe & 60 \\
\hline 70 & $1995 / 03$ & $1995 / 08$ & Santa Fe & 30 \\
\hline 70 & $1995 / 09$ & $1995 / 10$ & Santa Fe & 40 \\
\hline
\end{tabular}




\begin{tabular}{|c|c|c|c|}
\hline 70 & 1995/11 & $1995 / 12$ & Santa Fe \\
\hline 70 & 1996/01 & & Santa Fe \\
\hline 71 & 1994/07 & $1995 / 02$ & Santa Fe \\
\hline 71 & 1995/03 & 1995/08 & Santa Fe \\
\hline 71 & 1995/09 & $1995 / 10$ & Santa Fe \\
\hline 71 & $1995 / 11$ & $1995 / 12$ & Santa Fe \\
\hline 71 & 1996/01 & & Santa Fe \\
\hline 72 & 1994/07 & $1995 / 02$ & Santa Fe \\
\hline 72 & $1995 / 03$ & $1995 / 08$ & Santa Fe \\
\hline 72 & 1995/09 & $1995 / 10$ & Santa Fe \\
\hline 72 & 1995/11 & $1995 / 12$ & Santa Fe \\
\hline 72 & 1996/01 & & Santa Fe \\
\hline 73 & $1994 / 07$ & $1995 / 02$ & Santa Fe \\
\hline 73 & $1995 / 03$ & $1995 / 08$ & Santa Fe \\
\hline 73 & 1995/09 & $1995 / 10$ & Santa Fe \\
\hline 73 & 1995/11 & $1995 / 12$ & Santa Fe \\
\hline 73 & 1996/01 & & Santa Fe \\
\hline 74 & $1994 / 07$ & $1995 / 02$ & Santa Fe \\
\hline 74 & $1995 / 03$ & $1995 / 08$ & Santa Fe \\
\hline 74 & $1995 / 09$ & $1995 / 10$ & Santa Fe \\
\hline 74 & 1995/11 & $1995 / 12$ & Santa Fe \\
\hline 74 & 1996/01 & & Santa Fe \\
\hline 75 & 1994/07 & $1995 / 02$ & Santa Fe \\
\hline 75 & 1995/03 & 1995/08 & Santa Fe \\
\hline 75 & 1995/09 & $1995 / 10$ & Santa Fe \\
\hline 75 & $1995 / 11$ & $1995 / 12$ & Santa Fe \\
\hline 75 & 1996/01 & & Santa Fe \\
\hline 76 & 1994/07 & $1995 / 02$ & Santiago del Estero \\
\hline 76 & $1995 / 03$ & $1995 / 08$ & Santiago del Estero \\
\hline 76 & 1995/09 & $1995 / 10$ & Santiago del Estero \\
\hline 76 & 1995/11 & $1995 / 12$ & Santiago del Estero \\
\hline 76 & 1996/01 & & Santiago del Estero \\
\hline 77 & 1994/07 & $1995 / 02$ & Santiago del Estero \\
\hline 77 & $1995 / 03$ & $1995 / 08$ & Santiago del Estero \\
\hline 77 & $1995 / 09$ & $1995 / 10$ & Santiago del Estero \\
\hline 77 & 1995/11 & $1995 / 12$ & Santiago del Estero \\
\hline 77 & 1996/01 & & Santiago del Estero \\
\hline 78 & 1994/07 & $1995 / 02$ & Santiago del Estero \\
\hline 78 & $1995 / 03$ & 1995/08 & Santiago del Estero \\
\hline 78 & 1995/09 & $1995 / 10$ & Santiago del Estero \\
\hline 78 & 1995/11 & $1995 / 12$ & Santiago del Estero \\
\hline 78 & 1996/01 & & Santiago del Estero \\
\hline 79 & $1994 / 07$ & $1995 / 02$ & Santiago del Estero \\
\hline 79 & $1995 / 03$ & 1995/08 & Santiago del Estero \\
\hline 79 & 1995/09 & $1995 / 10$ & Santiago del Estero \\
\hline
\end{tabular}

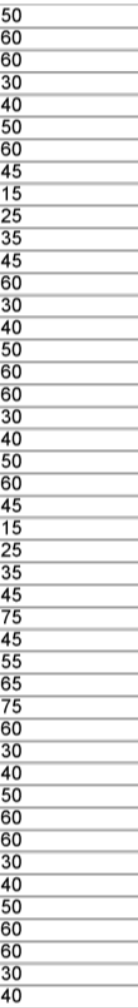

Página

\begin{tabular}{|l|l|l|l|l|}
\hline 79 & $1995 / 11$ & $1995 / 12$ & Santiago del Estero & 50 \\
\hline 79 & $1996 / 01$ & & Santiago del Estero & 60 \\
\hline 80 & $1994 / 07$ & $1995 / 02$ & Santiago del Estero & 80 \\
\hline 80 & $195 / 03$ & $1995 / 08$ & Santiago del Estero & 50 \\
\hline 80 & $1995 / 09$ & $1995 / 10$ & Santiago del Estero & 60 \\
\hline 80 & $1995 / 11$ & $1995 / 12$ & Santiago del Estero & 70 \\
\hline 80 & $1996 / 01$ & & Santiago del Estero & 80 \\
\hline 81 & $1994 / 07$ & $1995 / 02$ & Tierra del Fuego & 65 \\
\hline 81 & $1995 / 03$ & $1995 / 08$ & Tierra del Fuego & 35 \\
\hline 81 & $1995 / 09$ & $1995 / 10$ & Tierra del Fuego & 45 \\
\hline 81 & $1995 / 11$ & $1995 / 12$ & Tierra del Fuego & 55 \\
\hline 81 & $1996 / 01$ & & Tierra del Fuego & 65 \\
\hline 82 & $1994 / 07$ & $1995 / 02$ & Tierra del Fuego & 65 \\
\hline 82 & $1995 / 03$ & $1995 / 08$ & Tierra del Fuego & 35 \\
\hline 82 & $1995 / 09$ & $1995 / 10$ & Tierra del Fuego & 45 \\
\hline 82 & $1995 / 11$ & $1995 / 12$ & Tierra del Fuego & 55 \\
\hline 83 & $1996 / 01$ & & Tierra del Fuego & 65 \\
\hline 83 & $1994 / 07$ & $1995 / 02$ & Tierra del Fuego & 70 \\
\hline 83 & $1995 / 03$ & $1995 / 08$ & Tierra del Fuego & 50 \\
\hline 83 & $1995 / 09$ & $1995 / 10$ & Tierra del Fuego & 60 \\
\hline 84 & $1995 / 11$ & $1995 / 12$ & Tierra del Fuego & 70 \\
\hline 84 & $1996 / 01$ & & Tierra del Fuego & 60 \\
\hline 84 & $1994 / 07$ & $1995 / 02$ & Tucumán & 30 \\
\hline 84 & $195 / 03$ & $1995 / 08$ & Tucumán & 40 \\
\hline 85 & $1995 / 09$ & $1995 / 10$ & Tucumán & 50 \\
\hline 85 & $1995 / 11$ & $1995 / 12$ & Tucumán & 60 \\
\hline 85 & $1996 / 01$ & & Tucumán & 65 \\
\hline 85 & $1994 / 07$ & $1995 / 02$ & Tucumán & 35 \\
\hline & $1995 / 03$ & $1995 / 08$ & Tucumán & 45 \\
\hline
\end{tabular}




\section{Appendix to Executive order ("Decreto") 2609/1993}

ANEXO I

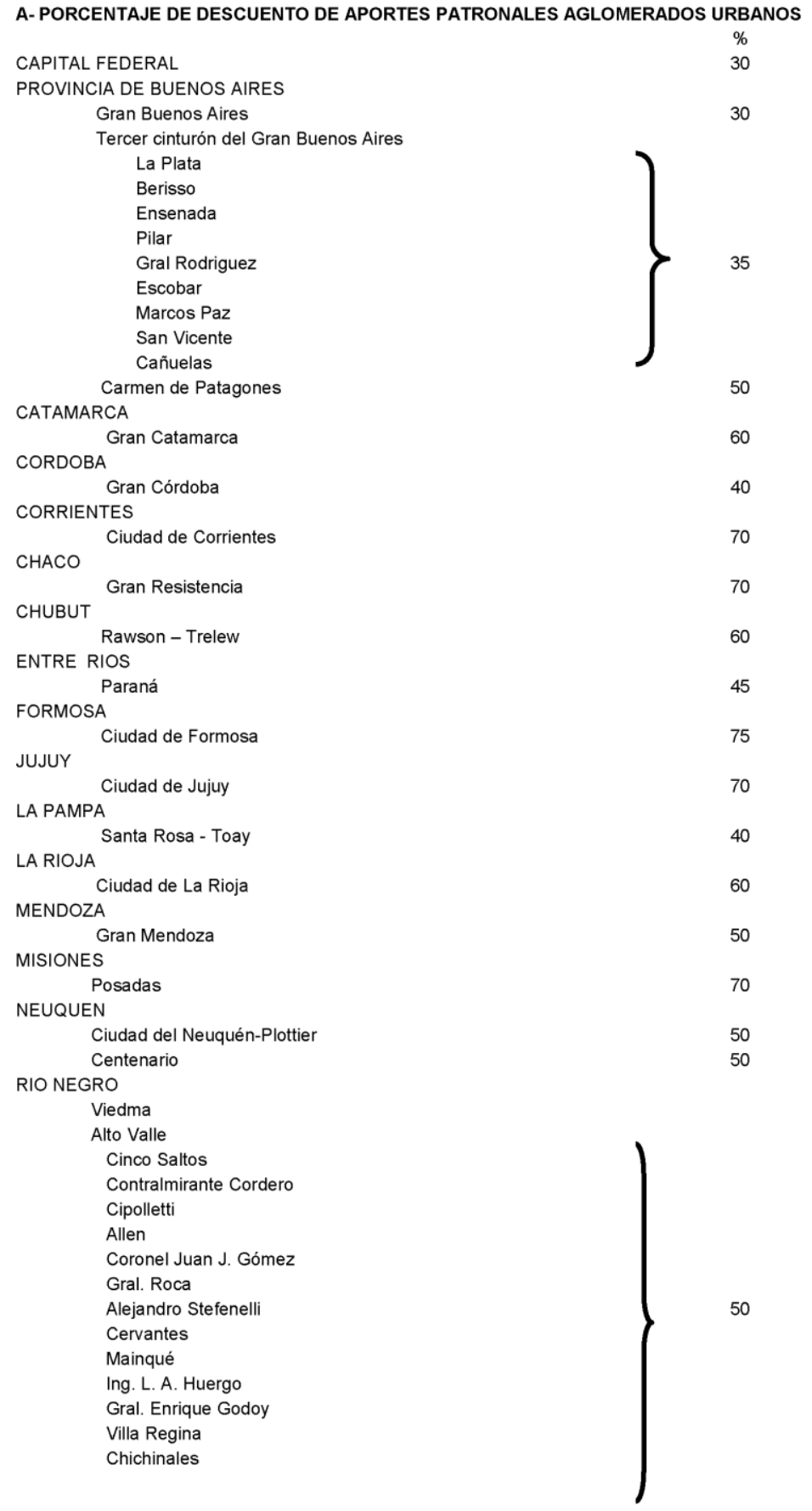


Fernández Oro

SALTA

$\begin{array}{ll}\text { Gran Salta } & 70\end{array}$

SAN JUAN

Gran San Juan

SAN LUIS

Ciudad de San Luis $\quad 50$

SANTA CRUZ

Caleta Olivia $\quad 65$

Rio Gallegos $\quad 65$

SANTA FE

Santa Fe - Santo Tomé

SANTIAGO DEL ESTERO

Ciudad de Sgo. Del Estero - La Banda $\quad 75$

TIERRA DEL FUEGO

Rio Grande

Usuahia

65

65

TUCUMAN

Gran Tucumán

ANEXO I

B- PORCENTAJE DE DESCUENTO DE APORTES PATRONALES PARA CADA PROVINCIA EXCEPTO LOS CORRESPONDIENTE A LAS CIUDADES CAPITALES Y PRINCIPALES AGLOMERACIONES QUE SE DETALLAN EN EL ANEXO I-A

\begin{tabular}{|l|l}
\hline CAPITAL FEDERAL & 30
\end{tabular}

PROVINCIA DE BUENOS AIRES

Gran Buenos Aires

\begin{tabular}{|c|c|c|}
\hline \multicolumn{3}{|c|}{ Gran Buenos Alres } \\
\hline & Almirante Brown & \\
\hline & Avellaneda & \\
\hline & Berazategui & \\
\hline & Esteban Echeverria & \\
\hline & Florencio Varela & \\
\hline & Gral. San Martin & \\
\hline & Gral. Sarmiento & \\
\hline & La Matanza & \\
\hline & Lanús & 30 \\
\hline & Lomas de Zamora & \\
\hline & Merlo & \\
\hline & Moreno & \\
\hline & Morón & \\
\hline & Quilmes & \\
\hline & San Fernando & \\
\hline & San Isidro & \\
\hline & Tigre & \\
\hline & Tres de Febrero & \\
\hline & Vicente López & \\
\hline La Plata & & \\
\hline Ensenad & & \\
\hline Berisso & & \\
\hline Escobar & & \\
\hline Pilar & & 35 \\
\hline Gral. Rod & iguez & \\
\hline Marcos $\mathrm{Pe}$ & & \\
\hline San Vicen & & \\
\hline Cañuelas & & \\
\hline Patagones & & 45 \\
\hline Villarino & & 45 \\
\hline Resto de I & ss partidos de la Prov. De Bs. As. & 40 \\
\hline CATAMARCA & & 65 \\
\hline
\end{tabular}




\begin{tabular}{|c|c|c|}
\hline CORDOBA & & \\
\hline Sobremon & 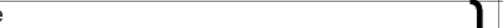 & \\
\hline Río Seco & $\zeta$ & 60 \\
\hline Tulumba & & \\
\hline Cruz del Ej & 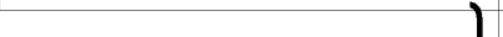 & \\
\hline Minas & & \\
\hline Pocho & + & 55 \\
\hline San Albertc & & \\
\hline San Javier & $\int$ & \\
\hline Resto de los & dptos de la Prov. De Córdoba & 45 \\
\hline CORRIENTES & & \\
\hline Esquina & ) & \\
\hline Sauce & L & 60 \\
\hline Curuzú- Cua & ia & \\
\hline Monte Case & s & \\
\hline Resto de los & dptos de la Prov. de Corrientes & 70 \\
\hline $\mathrm{CHACO}$ & & 80 \\
\hline CHUBUT & & 65 \\
\hline ENTRE RIOS & & \\
\hline Feliciano & & 60 \\
\hline Federación & & \\
\hline Resto de los & dptos de la Prov. de E. Ríos & 50 \\
\hline FORMOSA & & 80 \\
\hline JUJUY & & 75 \\
\hline LA PAMPA & & \\
\hline Chical-C & ) & \\
\hline Chalileo & & \\
\hline Peulén & & 55 \\
\hline Limay-N & huida & \\
\hline Curacó & & \\
\hline Lihuel- C & lel & \\
\hline Resto de los & dptos de la Prov. de E. Ríos & 45 \\
\hline LA RIOJA & & 65 \\
\hline MENDOZA & & 55 \\
\hline MISIONES & & 75 \\
\hline NEUQUEN & & 55 \\
\hline RIO NEGRO & & \\
\hline $\begin{array}{l}\text { Toda la prov. de } \\
\text { del } 10-07-92 \text {, (re } \\
\text { transferencias d }\end{array}$ & $\begin{array}{l}\text { R. Negro excepto el área delimitada por el Dto. } 1161 \\
\text { erido a la eliminación de impuestos a las } \\
\text { combustibles en el sur de pais }\end{array}$ & 55 \\
\hline $\begin{array}{l}\text { Area delimitada } \\
\text { paralelo } 42 \text { ) }\end{array}$ & or el Dec 1161 (comprende el sur de la prov hasta el & 65 \\
\hline SALTA & & 75 \\
\hline SAN JUAN & & 60 \\
\hline SAN LUIS & & 55 \\
\hline SANTA CRUZ & & 70 \\
\hline SANTA FE & & \\
\hline Gral Obli & ado & \\
\hline San Javi & & \\
\hline 9 de Juli & & 60 \\
\hline Vera & & \\
\hline Resto de los & dptos de la Prov. de Sta. Fe & 45 \\
\hline SANTIAGO DEL & ESTERO & \\
\hline Ojo de $A c$ & & \\
\hline Quebrach & & 60 \\
\hline Rivadavia & & \\
\hline Resto de los & dptos de la Prov. de Sgo. del Estero & 80 \\
\hline TIERRA DEL FL & EGO & 70 \\
\hline
\end{tabular}




\begin{tabular}{|c|c|c|c|c|c|c|}
\hline TUCUMAN & & & & 65 & & \\
\hline \multicolumn{7}{|l|}{ ANEXO II } \\
\hline \multicolumn{7}{|c|}{ NUEVAS ALICUOTAS APLICABLES } \\
\hline & & & & & & \\
\hline$\%$ de dto. & a) & b) & c) & d) & e) & Total \\
\hline 30 & 11,20 & 5,30 & 1,00 & 1,40 & 4,20 & 23,10 \\
\hline 35 & 10,40 & 4,90 & 1,00 & 1,30 & 3,90 & 21,50 \\
\hline 40 & 9,60 & 4,50 & 0,90 & 1,20 & 3,60 & 19,80 \\
\hline 45 & 8,80 & 4,20 & 0,80 & 1,10 & 3,30 & 18,20 \\
\hline 50 & 8,00 & 3,80 & 0,70 & 1,00 & 3,00 & 16,50 \\
\hline 55 & 7,20 & 3,40 & 0,70 & 0,90 & 2,70 & 14,90 \\
\hline 60 & 6,40 & 3,00 & 0,60 & 0,80 & 2,40 & 13,20 \\
\hline 65 & 5,60 & 2,70 & 0,50 & 0,70 & 2,10 & 11,60 \\
\hline 70 & 4,80 & 2,30 & 0,40 & 0,60 & 1,80 & 9,90 \\
\hline 75 & 4,00 & 1,90 & 0,40 & 0,50 & 1,50 & 8,30 \\
\hline 80 & 3,20 & 1,50 & 0,30 & 0,40 & 1,20 & 6,60 \\
\hline
\end{tabular}

a) Régimen Nacional de Jubilaciones y Pensiones para Trabajadores en Relación de depencia

b) Ex Cajas de Subsidios Familiares

c) Fondo Nacional de Empleo

d) Instituto Nacional de Servicios Sociales para Jubilados y Pensionados

e) Régimen de Obras Sociales 


\section{SERIE DOCUMENTOS DE TRABAJO DEL CEDLAS}

Todos los Documentos de Trabajo del CEDLAS están disponibles en formato electrónico en 〈www.depeco.econo.unlp.edu.ar/cedlas〉.

- Nro. 93 (Enero, 2010). Guillermo Cruces, Sebastian Galiani y Susana Kidyba. Payroll Taxes, Wages and Employment: Identification through Policy Changes.

- Nro. 92 (Diciembre, 2009). Mauricio Zunino. "Impactos de la Reinstauración de los Consejos de Salarios sobre la Distribución Salarial en Uruguay: Conclusiones, Hipótesis e Interrogantes".

- Nro. 91 (Diciembre, 2009). María Laura Alzúa, Catherine Rodriguez y Edgar Villa. "The Quality of Life in Prisons: Do Educational Programs Reduce In-prison Conflicts?".

- Nro. 90 (Noviembre, 2009). Diego Battiston, Guillermo Cruces, Luis Felipe Lopez Calva, Maria Ana Lugo y Maria Emma Santos. "Income and Beyond: Multidimensional Poverty in Six Latin American countries".

- Nro. 89 (Octubre, 2009). Mariana Viollaz, Sergio Olivieri y Javier Alejo. "Labor Income Polarization in Greater Buenos Aires".

- Nro. 88 (Septiembre, 2009). Sebastian Galiani. "Reducing Poverty in Latin America and the Caribbean".

- Nro. 87 (Agosto, 2009). Pablo Gluzmann y Federico Sturzenegger. "An Estimation of CPI Biases in Argentina 1985-2005, and its Implications on Real Income Growth and Income Distribution".

- Nro. 86 (Julio, 2009). Mauricio Gallardo Altamirano. "Estimación de Corte Transversal de la Vulnerabilidad y la Pobreza Potencial de los Hogares en Nicaragua".

- Nro. 85 (Junio, 2009). Rodrigo López-Pablos. "Una Aproximación Antropométrica a la Medición de la Pobreza".

- Nro. 84 (Mayo, 2009). Maribel Jiménez y Mónica Jiménez. "La Movilidad Intergeneracional del Ingreso: Evidencia para Argentina".

- Nro. 83 (Abril, 2009). Leonardo Gasparini y Pablo Gluzmann "Estimating Income Poverty and Inequality from the Gallup World Poll: The Case of Latin America and the Caribbean".

- Nro. 82 (Marzo, 2009). Facundo Luis Crosta. "Reformas Administrativas y Curriculares: El Efecto de la Ley Federal de Educación sobre el Acceso a Educación Media". 
- Nro. 81 (Febrero, 2009). Leonardo Gasparini, Guillermo Cruces, Leopoldo Tornarolli y Mariana Marchionni. "A Turning Point? Recent Developments on Inequality in Latin America and the Caribbean".

- Nro. 80 (Enero, 2009). Ricardo N. Bebczuk. "SME Access to Credit in Guatemala and Nicaragua: Challenging Conventional Wisdom with New Evidence".

- Nro. 79 (Diciembre, 2008). Gabriel Sánchez, María Laura Alzúa e Inés Butler. "Impact of Technical Barriers to Trade on Argentine Exports and Labor Markets".

- Nro. 78 (Noviembre, 2008). Leonardo Gasparini y Guillermo Cruces. "A Distribution in Motion: The Case of Argentina".

- Nro. 77 (Noviembre, 2008). Guillermo Cruces y Leonardo Gasparini. "Programas Sociales en Argentina: Alternativas para la Ampliación de la Cobertura".

- Nro. 76 (Octubre, 2008). Mariana Marchionni y Adriana Conconi. "¿Qué y a Quién? Beneficios y Beneficiarios de los Programas de Transferencias Condicionadas de Ingresos".

- Nro. 75 (Septiembre, 2008). Marcelo Bérgolo y Fedora Carbajal. "Brecha Urbano Rural de Ingresos Laborales en Uruguay para el Año 2006: Una Descomposición por Cuantiles".

- Nro. 74 (Agosto, 2008). Matias D. Cattaneo, Sebastian Galiani, Paul J. Gertler, Sebastian Martinez y Rocio Titiunik. "Housing, Health and Happiness".

- Nro. 73 (Agosto, 2008). María Laura Alzúa. "Are Informal Workers Secondary Workers?: Evidence for Argentina".

- Nro. 72 (Julio, 2008). Carolina Díaz-Bonilla, Hans Lofgren y Martín Cicowiez. "Public Policies for the MDGs: The Case of the Dominican Republic".

- Nro. 71 (Julio, 2008). Leonardo Gasparini, Facundo Crosta, Francisco Haimovich, Beatriz Alvarez, Andrés Ham y Raúl Sánchez. "Un Piso de Protección Social en América Latina: Costos Fiscales e Impactos Sociales".

- Nro. 70 (Junio, 2008). Mariana Viollaz. "Polarización de ingresos laborales: Argentina 1992-2006".

- Nro. 69 (Mayo, 2008). Mariana Marchionni, Walter Sosa Escudero y Javier Alejo. "Efectos Distributivos de Esquemas Alternativos de Tarifas Sociales: Una Exploración Cuantitativa".

- Nro. 68 (Mayo, 2008). Ricardo N. Bebczuk. "Financial Inclusion in Latin America and the Caribbean: Review and Lessons".

- Nro. 67 (Abril, 2008). Mariana Marchionni, Walter Sosa Escudero y Javier Alejo. "La Incidencia Distributiva del Acceso, Gasto y Consumo de los Servicios Públicos". 
- Nro. 66 (Abril, 2008). Ricardo N. Bebczuk. "Dolarización y Pobreza en Ecuador".

- Nro. 65 (Marzo, 2008). Walter Sosa Escudero and Anil K. Bera. "Tests for Unbalanced Error Component Models Under Local Misspecication".

- Nro. 64 (Febrero, 2008). Luis Casanova. "Trampas de Pobreza en Argentina: Evidencia Empírica a Partir de un Pseudo Panel".

- Nro. 63 (Enero, 2008). Francisco Franchetti y Diego Battistón. "Inequality in Health Coverage, Empirical Analysis with Microdata for Argentina 2006".

- Nro. 62 (Diciembre, 2007). Adriana Conconi, Guillermo Cruces, Sergio Olivieri y Raúl Sánchez. "E pur si muove? Movilidad, Pobreza y Desigualdad en América Latina".

- Nro. 61 (Diciembre, 2007). Mariana Marchionni, Germán Bet y Ana Pacheco. "Empleo, Educación y Entorno Social de los Jóvenes: Una Nueva Fuente de Información".

- Nro. 60 (Noviembre, 2007). María Gabriela Farfán y María Florencia Ruiz Díaz. "Discriminación Salarial en la Argentina: Un Análisis Distributivo".

- Nro. 59 (Octubre, 2007). Leopoldo Tornarolli y Adriana Conconi. "Informalidad y Movilidad Laboral: Un Análisis Empírico para Argentina".

- Nro. 58 (Septiembre, 2007). Leopoldo Tornarolli. "Metodología para el Análisis de la Pobreza Rural".

- Nro. 57 (Agosto, 2007). Adriana Conconi y Andrés Ham. "Pobreza Multidimensional Relativa: Una Aplicación a la Argentina".

- Nro. 56 (Agosto, 2007). Martín Cicowiez, Luciano Di Gresia y Leonardo Gasparini. "Politicas Públicas y Objetivos de Desarrollo del Milenio en la Argentina".

- Nro. 55 (Julio, 2007). Leonardo Gasparini, Javier Alejo, Francisco Haimovich, Sergio Olivieri y Leopoldo Tornarolli. "Poverty among the Elderly in Latin America and the Caribbean".

- Nro. 54 (Julio, 2007). Gustavo Javier Canavire-Bacarreza y Luís Fernando Lima Soria. "Unemployment Duration and Labor Mobility in Argentina: A Socioeconomic-Based Pre- and Post-Crisis Analysis".

- Nro. 53 (Junio, 2007). Leonardo Gasparini, Francisco Haimovich y Sergio Olivieri. "Labor Informality Effects of a Poverty-Alleviation Program".

- Nro. 52 (Junio, 2007). Nicolás Epele y Victoria Dowbley. "Análisis Ex-Ante de un Aumento en la Dotación de Capital Humano: El Caso del Plan Familias de Transferencias Condicionadas". 
- Nro. 51 (Mayo, 2007). Jerónimo Carballo y María Bongiorno. "Vulnerabilidad Individual: Evolución, Diferencias Regionales e Impacto de la Crisis. Argentina 1995 - 2005".

- Nro. 50 (Mayo, 2007). Paula Giovagnoli. "Failures in School Progression".

- Nro. 49 (Abril, 2007). Sebastian Galiani, Daniel Heymann, Carlos Dabús y Fernando Tohmé. "Land-Rich Economies, Education and Economic Development".

- Nro. 48 (Abril, 2007). Ricardo Bebczuk y Francisco Haimovich. "MDGs and Microcredit: An Empirical Evaluation for Latin American Countries".

- Nro. 47 (Marzo, 2007). Sebastian Galiani y Federico Weinschelbaum. "Modeling Informality Formally: Households and Firms".

- Nro. 46 (Febrero, 2007). Leonardo Gasparini y Leopoldo Tornarolli. "Labor Informality in Latin America and the Caribbean: Patterns and Trends from Household Survey Microdata".

- Nro. 45 (Enero, 2007). Georgina Pizzolitto. "Curvas de Engel de Alimentos, Preferencias Heterogéneas y Características Demográficas de los Hogares: Estimaciones para Argentina".

- Nro. 44 (Diciembre, 2006). Rafael Di Tella, Sebastian Galiani y Ernesto Schargrodsky. "Crime Distribution and Victim Behavior during a Crime Wave".

- Nro. 43 (Noviembre, 2006). Martín Cicowiez, Leonardo Gasparini, Federico Gutiérrez y Leopoldo Tornarolli. "Areas Rurales y Objetivos de Desarrollo del Milenio en America Latina y El Caribe".

- Nro. 42 (Octubre, 2006). Martín Guzmán y Ezequiel Molina. "Desigualdad e Instituciones en una Dimensión Intertemporal".

- Nro. 41 (Septiembre, 2006). Leonardo Gasparini y Ezequiel Molina. "Income Distribution, Institutions and Conflicts: An Exploratory Analysis for Latin America and the Caribbean".

- Nro. 40 (Agosto, 2006). Leonardo Lucchetti. "Caracterización de la Percepción del Bienestar y Cálculo de la Línea de Pobreza Subjetiva en Argentina".

- Nro. 39 (Julio, 2006). Héctor Zacaria y Juan Ignacio Zoloa. "Desigualdad y Pobreza entre las Regiones Argentinas: Un Análisis de Microdescomposiciones".

- Nro. 38 (Julio, 2006). Leonardo Gasparini, Matías Horenstein y Sergio Olivieri. "Economic Polarisation in Latin America and the Caribbean: What do Household Surveys Tell Us?".

- Nro. 37 (Junio, 2006). Walter Sosa-Escudero, Mariana Marchionni y Omar Arias. "Sources of Income Persistence: Evidence from Rural El Salvador". 
- Nro. 36 (Mayo, 2006). Javier Alejo. "Desigualdad Salarial en el Gran Buenos Aires: Una Aplicación de Regresión por Cuantiles en Microdescomposiciones".

- Nro. 35 (Abril, 2006). Jerónimo Carballo y María Bongiorno. "La Evolución de la Pobreza en Argentina: Crónica, Transitoria, Diferencias Regionales y Determinantes (1995-2003)".

- Nro. 34 (Marzo, 2006). Francisco Haimovich, Hernán Winkler y Leonardo Gasparini. "Distribución del Ingreso en América Latina: Explorando las Diferencias entre Países".

- Nro. 33 (Febrero, 2006). Nicolás Parlamento y Ernesto Salinardi. "Explicando los Cambios en la Desigualdad: Son Estadísticamente Significativas las Microsimulaciones? Una Aplicación para el Gran Buenos Aires".

- Nro. 32 (Enero, 2006). Rodrigo González. "Distribución de la Prima Salarial del Sector Público en Argentina".

- Nro. 31 (Enero, 2006). Luis Casanova. "Análisis estático y dinámico de la pobreza en Argentina: Evidencia Empírica para el Periodo 1998-2002".

- Nro. 30 (Diciembre, 2005). Leonardo Gasparini, Federico Gutiérrez y Leopoldo Tornarolli. "Growth and Income Poverty in Latin America and the Caribbean: Evidence from Household Surveys".

- Nro. 29 (Noviembre, 2005). Mariana Marchionni. "Labor Participation and Earnings for Young Women in Argentina".

- Nro. 28 (Octubre, 2005). Martín Tetaz. "Educación y Mercado de Trabajo".

- Nro. 27 (Septiembre, 2005). Matías Busso, Martín Cicowiez y Leonardo Gasparini. "Ethnicity and the Millennium Development Goals in Latin America and the Caribbean".

- Nro. 26 (Agosto, 2005). Hernán Winkler. "Monitoring the Socio-Economic Conditions in Uruguay".

- Nro. 25 (Julio, 2005). Leonardo Gasparini, Federico Gutiérrez y Guido G. Porto. "Trade and Labor Outcomes in Latin America's Rural Areas: A Cross-Household Surveys Approach".

- Nro. 24 (Junio, 2005). Francisco Haimovich y Hernán Winkler. "Pobreza Rural y Urbana en Argentina: Un Análisis de Descomposiciones".

- Nro. 23 (Mayo, 2005). Leonardo Gasparini y Martín Cicowiez. "Meeting the Poverty-Reduction MDG in the Southern Cone".

- Nro. 22 (Abril, 2005). Leonardo Gasparini y Santiago Pinto. "Equality of Opportunity and Optimal Cash and In-Kind Policies". 
- Nro. 21 (Abril, 2005). Matías Busso, Federico Cerimedo y Martín Cicowiez. "Pobreza, Crecimiento y Desigualdad: Descifrando la Última Década en Argentina".

- Nro. 20 (Marzo, 2005). Georgina Pizzolitto. "Poverty and Inequality in Chile: Methodological Issues and a Literature Review".

- Nro. 19 (Marzo, 2005). Paula Giovagnoli, Georgina Pizzolitto y Julieta Trías. "Monitoring the Socio-Economic Conditions in Chile".

- Nro. 18 (Febrero, 2005). Leonardo Gasparini. "Assessing Benefit-Incidence Results Using Decompositions: The Case of Health Policy in Argentina".

- Nro. 17 (Enero, 2005). Leonardo Gasparini. "Protección Social y Empleo en América Latina: Estudio sobre la Base de Encuestas de Hogares".

- Nro. 16 (Diciembre, 2004). Evelyn Vezza. "Poder de Mercado en las Profesiones Autorreguladas: El Desempeño Médico en Argentina".

- Nro. 15 (Noviembre, 2004). Matías Horenstein y Sergio Olivieri. "Polarización del Ingreso en la Argentina: Teoría y Aplicación de la Polarización Pura del Ingreso".

- Nro. 14 (Octubre, 2004). Leonardo Gasparini y Walter Sosa Escudero. "Implicit Rents from Own-Housing and Income Distribution: Econometric Estimates for Greater Buenos Aires".

- Nro. 13 (Septiembre, 2004). Monserrat Bustelo. "Caracterización de los Cambios en la Desigualdad y la Pobreza en Argentina Haciendo Uso de Técnicas de Descomposiciones Microeconometricas (1992-2001)".

- Nro. 12 (Agosto, 2004). Leonardo Gasparini, Martín Cicowiez, Federico Gutiérrez y Mariana Marchionni. "Simulating Income Distribution Changes in Bolivia: a Microeconometric Approach".

- Nro. 11 (Julio, 2004). Federico H. Gutierrez. "Dinámica Salarial y Ocupacional: Análisis de Panel para Argentina 1998-2002".

- Nro. 10 (Junio, 2004). María Victoria Fazio. "Incidencia de las Horas Trabajadas en el Rendimiento Académico de Estudiantes Universitarios Argentinos".

- Nro. 9 (Mayo, 2004). Julieta Trías. "Determinantes de la Utilización de los Servicios de Salud: El Caso de los Niños en la Argentina".

- Nro. 8 (Abril, 2004). Federico Cerimedo. "Duración del Desempleo y Ciclo Económico en la Argentina".

- Nro. 7 (Marzo, 2004). Monserrat Bustelo y Leonardo Lucchetti. "La Pobreza en Argentina: Perfil, Evolución y Determinantes Profundos (1996, 1998 Y 2001)".

- Nro. 6 (Febrero, 2004). Hernán Winkler. "Estructura de Edades de la Fuerza Laboral y Distribución del Ingreso: Un Análisis Empírico para la Argentina". 
- Nro. 5 (Enero, 2004). Pablo Acosta y Leonardo Gasparini. "Capital Accumulation, Trade Liberalization and Rising Wage Inequality: The Case of Argentina".

- Nro. 4 (Diciembre, 2003). Mariana Marchionni y Leonardo Gasparini. "Tracing Out the Effects of Demographic Changes on the Income Distribution. The Case of Greater Buenos Aires".

- Nro. 3 (Noviembre, 2003). Martín Cicowiez. "Comercio y Desigualdad Salarial en Argentina: Un Enfoque de Equilibrio General Computado".

- Nro. 2 (Octubre, 2003). Leonardo Gasparini. "Income Inequality in Latin America and the Caribbean: Evidence from Household Surveys".

- Nro. 1 (Septiembre, 2003). Leonardo Gasparini. "Argentina's Distributional Failure: The Role of Integration and Public Policies". 